\title{
A NEW STRATEGY FOR REGULATING ARBITRATION
}

\section{Sarath Sanga}

\begin{abstract}
Confidential arbitration is a standard precondition to employment. But confidential arbitration prevents a state from ensuring or even knowing whether employees' economic, civil, and due process rights are respected. Further, employers regularly require employees to waive rights to class proceedings (thereby foreclosing small claims) and to arbitrate under the laws of another jurisdiction (thereby evading mandatory state law). In response, states have tried to regulate arbitration provisions, arbitral awards, and arbitral processes. But these efforts have all failed because the Supreme Court says they are preempted by the Federal Arbitration Act.

In this Article, I argue that states can and should adopt a new strategy: Deter parties from forming such contracts in the first place.

The Article proceeds in three parts. First, I explain the problem. Over the last fifty years, the Supreme Court systematically immunized arbitration provisions against every plausible contract defense. Yet the Supreme Court continues to insist that, just as the Federal Arbitration Act requires, arbitration agreements are still subject to "generally applicable contract defenses, such as fraud, duress, or unconscionability." This is false.

Second, I present the first large-scale evidence on the pervasiveness of arbitration. The Supreme Court's arbitration precedents have effect only to the extent private parties agree to arbitrate their disputes. To study this, I use machine-learning protocols to parse millions of filings with the Securities and Exchange Commission and create a database of nearly 800,000 contracts formed by public companies. These contracts include employment agreements, credit agreements, joint ventures, purchases, and others. Employment contracts are by far the most likely to include a mandatory arbitration provision.

Finally, I argue that, because the Supreme Court has all but stripped states of their power to enforce contracts, states should adopt policies that deter formation of objectionable contracts. For example, states cannot prohibit forced arbitration of sexual harassment claims. They can, however, prohibit sexual harassment as a subject matter for employment contracts;
\end{abstract}

${ }^{1}$ Doctor's Assocs., Inc. v. Casarotto, 517 U.S. 681, 687 (1996). 
they can also enforce this with civil penalties and whistleblower rewards. Similarly, states cannot stop an employer from arbitrating under the laws of another jurisdiction, thereby evading mandatory limits on noncompete agreements. But states can declare noncompetes illegal, levy civil fines on employers that form them, and again offer employees whistleblower rewards to report violations. These approaches work because they create a cause of action for a third party - the state - who is not subject to the arbitration agreement. And unlike past efforts, these laws would not be preempted because they do not "derive their meaning from the fact that an agreement to arbitrate is at issue."

AUTHOR-Assistant Professor, Northwestern University Pritzker School of Law. I thank Andrew Verstein, Max Schanzenbach, Roberta Romano, Jide Nzelibe, Daniel Hemel, Ezra Friedman, Christopher R. Drahozal, Shari Diamond, Richard R.W. Brooks, and Ian Ayres for very helpful comments. This research was supported by the Northwestern University Pritzker School of Law Faculty Research Program. Author's email: sanga@northwestern.edu.

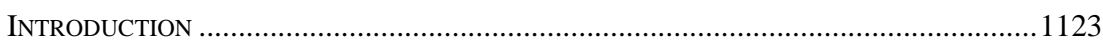

I. How States Lost CONTROL OVER Contract ENFORCEMENT ...........................1128

A. The Supreme Court's Position ...................................................................... 1128

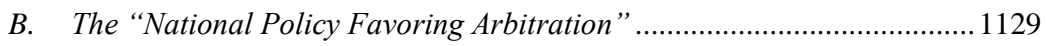

C. The End of Contract Defenses .............................................................. 1137

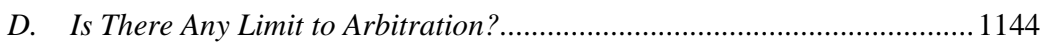

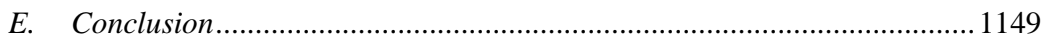

II. New Evidence on the Pervasiveness of Employment Arbitration........... 1149

A. Data Collection.......................................................................................... 1150

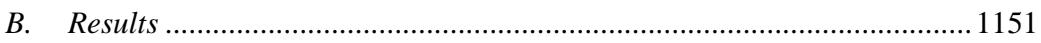

C. The Principal Challenge of Machine Learning in Empirical

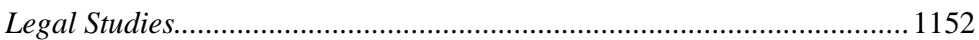

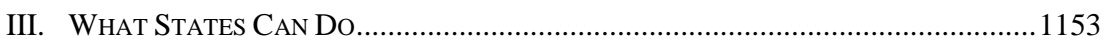

A. The Strategy: Deterrence over Enforcement............................................. 1153

B. Example 1: Indirect Enforcement ............................................................... 1154

C. Example 2: Preventing (Mandatory) Arbitration...................................... 1158

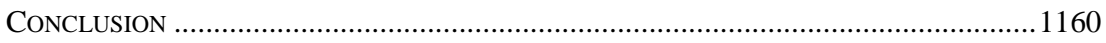

2 AT\&T Mobility LLC v. Concepcion, 563 U.S. 333, 339 (2011). 


\section{INTRODUCTION}

In Tishomingo, a small town in southern Oklahoma, Eddie Lee Howard entered into a seemingly unenforceable contract. ${ }^{3}$ Howard had agreed to work for Nitro-Lift, a company that supplies nitrogen to oil and gas extractors. He also agreed not to work for any competing business for two years after leaving Nitro-Lift. ${ }^{4}$ This last provision-a standard covenant not to compete-is valid and enforceable in nearly every state.

But not in Oklahoma. Under Oklahoma law,

[a] person who makes an agreement with an employer ... not to compete with the employer after the employment relationship has been terminated, shall be permitted to engage in the same business as that conducted by the former employer [and] ... any provision in a contract between an employer and an employee [to the contrary] shall be void and unenforceable. ${ }^{5}$

Howard put this law to the test. He left Nitro-Lift and immediately went to work for a competing business. He also filed suit in the District Court of Johnston County, Oklahoma, seeking a declaratory judgment that the covenant not to compete was void and unenforceable. As a matter of law, the noncompete was indeed void. But Howard had a problem: his contract also contained a broad arbitration agreement that required him to submit any dispute to an arbitrator. The Federal Arbitration Act (FAA), along with a mountain of Supreme Court precedent, left no doubt that this provision must be specifically enforced. ${ }^{6}$ Recognizing this, the trial court dutifully applied federal law and dismissed Howard's claim. ${ }^{7}$

The Oklahoma Supreme Court, however, had other ideas. It reversed the trial court and declared that "the existence of an arbitration agreement in an employment contract does not prohibit judicial review of the underlying agreement." The Oklahoma court must have known that it was clearly disregarding federal law, which unambiguously provides that an arbitration agreement in an employment contract does prohibit judicial review. ${ }^{9}$ Nevertheless, the Oklahoma Supreme Court issued a judgment in favor of Howard and voided the noncompete. Nitro-Lift appealed.

\footnotetext{
3 The facts come from Howard v. Nitro-Lift Techs., L.L.C., 273 P.3d 20, 24-25 (Okla. 2011).

${ }^{4} I d$. at $24 \mathrm{n}$.8. It further provided that a "competing business" was any business engaged in "the use of non-cryogenically generated nitrogen for applications on wellsites in the oil and gas industry in the United States." Id. (insertions omitted).

5 OKLa. Stat. AnN. tit. 15, § 219A(A)-(B) (West 2018).

${ }^{6}$ See infra Part I.

7 Howard, 273 P.3d at 25.

8 Id. at 23 .

9 See Circuit City Stores, Inc. v. Adams, 532 U.S. 105, 109 (2001); Southland Corp. v. Keating, 465 U.S. 1, 14-16 (1984).
} 
The U.S. Supreme Court summarily reversed. In a terse per curiam opinion, it admonished the Oklahoma Supreme Court for "disregard[ing] this Court's precedents on the FAA" 10 and "insist[ing] that its own jurisprudence control[led] this issue." 11 It also reminded Oklahoma of what should have been obvious: "[T]he FAA ... is "the supreme Law of the Land,"'12 and "once the Court has spoken, it is the duty of other courts to respect that understanding of the governing rule of law."13

The U.S. Supreme Court was correct. Yet the Oklahoma court had its reasons. The problem in Nitro-Lift v. Howard was that arbitration might have led to enforcement of the noncompete - in contravention of (seemingly) mandatory state law. Why? Because Howard's contract provided not only that arbitration would take place outside of Oklahoma (in Houston, Texas) but also, crucially, that the arbitrator would apply Louisiana law. Under Louisiana law, Howard's noncompete would be valid and enforceable. ${ }^{14}$

The result thus hinged on the forum. An Oklahoma court would disregard the choice of Louisiana law and void the noncompete. ${ }^{15}$ What is not clear, however, is whether an arbitrator would conduct the same conflict of laws analysis. In fact, the U.S. Supreme Court has all but encouraged arbitrators to ignore the "complexity and uncertainty" of conflict of laws and simply apply the law that the parties chose. ${ }^{16}$ If an arbitrator were to heed the U.S. Supreme Court's advice, apply Louisiana law, and issue an award upholding the noncompete, then the FAA would leave Oklahoma state courts no choice but to enforce that award, even if it clearly erred in its conflict of law analysis, and even if enforcement would contravene Oklahoma policy. ${ }^{17}$ Nitro-Lift teaches us what most sophisticated parties already know: contracts

10 Nitro-Lift Techs., L.L.C. v. Howard, 568 U.S. 17, 20 (2012).

${ }^{11} I d$. at 21 (alteration and internal quotation marks omitted).

12 Id. (quoting U.S. ConST. art. VI, § 1, cl. 2).

13 Id. (quoting Rivers v. Roadway Express, Inc., 511 U.S. 298, 312 (1994))

14 Section 23:921(C) of the Louisiana code provides:

Any person ... who is employed as an agent, servant, or employee may agree with his employer to refrain from carrying on or engaging in a business similar to that of the employer ... [for a period] not to exceed . . t two years from termination of employment.

LA. STAT. ANN. § 23:921(C) (2018) (emphasis added).

15 The Oklahoma Supreme Court referenced the parties' choice of Louisiana law, but did not even consider the potential conflicts analysis. Instead, it tacitly held that the Oklahoma statute applies regardless of the parties' choice of law. Howard v. Nitro-Lift Techs., L.L.C., 273 P.3d 20, 24, 26-29 (Okla. 2011).

${ }^{16}$ Circuit City Stores, Inc. v. Adams, 532 U.S. 105, 123 (2001); see infra Section III.B.

17 See 9 U.S.C. §§ 9-11 (2012) (providing the exclusive grounds for vacatur and modification of awards, which does not include public policy grounds); Southland Corp. v. Keating, 465 U.S. 1, 10 (1984), discussed in Section I.D, below. 
can bootstrap their way out of mandatory state law by pairing an arbitration provision with a choice of law clause. ${ }^{18}$

States, it would seem, are powerless to stop this. Under federal law and Supreme Court precedent, there is virtually no circumstance under which a state or federal court may refuse to enforce an arbitration agreement or arbitral award. ${ }^{19}$ Even awards that make egregious errors in law must be enforced. ${ }^{20}$ But states have an interest in ensuring the enforcement of their own laws. They also have an interest in ensuring certain procedural protections for employees that a confidential, one-on-one proceeding cannot provide. ${ }^{21}$ Given these interests and the constraints of federal arbitration law, what can states do?

In this Article, I propose a new strategy for states. The principle is to regulate contract formation, not contract enforcement. States should abandon contract enforcement as a policy lever - as federal arbitration law has all but forced this result. Instead, states should focus on deterring formation of contracts that would undermine state policies. This strategy leverages a simple fact: Arbitration requires a contract. Thus, no contract means no arbitration.

The Article proceeds in three Parts. Throughout, I focus on the case of employment arbitration.

Part I reviews the last fifty years of Supreme Court arbitration jurisprudence. The story, as I see it, is quite unsatisfying. Modern Supreme Court jurisprudence is primarily based not on the federal statute that governs arbitration (the FAA), but on a "national policy favoring arbitration." 22 The unsatisfying part is that this policy is a mistake - and not in the sense that it strikes the wrong balance. Rather, it is a mistake because it is based on an

18 On choice of law in contracts generally, see Sarath Sanga, Choice of Law: An Empirical Analysis, 11 J. EMPIRICAL LEGAL STUD. 894 (2014), which analyzed all choice of law clauses in material contracts disclosed to the Securities and Exchange Commission. The most common choice was New York (27\%), followed by Delaware (12\%), and California (11\%). Id. at 906 tbl.2.

19 See infra Part I (discussing Prima Paint Corp. v. Flood \& Conklin Mfg. Co., 388 U.S. 395 (1967)).

${ }^{20}$ See infra Section I.D.

21 Arbitrators are not under any obligation to adopt rules to ensure fairness of process in any part of the proceeding. Thus, basic rules such as service of process that apply in state and federal courts (e.g., FED. R. CIV. P. 5) do not apply in arbitration. Further, arbitrators are not under any obligation to justify their awards in any way, such as by giving reasons in writing or orally. United Steelworkers of Am. v. Enter. Wheel \& Car Corp., 363 U.S. 593, 598 (1960) ("Arbitrators have no obligation to the court to give their reasons for an award."). The sole limits on arbitral process are listed in 9 U.S.C. § 10. These are restricted to egregious cases such as fraud, corruption, or refusal to hear evidence from one side.

${ }^{22}$ See Southland Corp. v. Keating, 465 U.S. 1, 10 (1984) ("In enacting $§ 2$ of the [FAA], Congress declared a national policy favoring arbitration."). 
erroneous citation to an early Supreme Court case, a case that all but expressly concludes that no such policy exists. ${ }^{23}$

Beginning in the 1984 case of Southland Corp. v. Keating ${ }^{24}$ and continuing to the present, the Supreme Court leveraged this policy to both expand the scope of the FAA and effectively eliminate its primary exception..$^{25}$ The primary exception, found in Section 2, provides that agreements to arbitrate are generally enforceable "save upon such grounds as exist at law or in equity for the revocation of any contract." ${ }^{26}$ Over the decades, the Court refined its interpretation of this so-called "saving clause," systematically foreclosing nearly all plausible contract defenses. It has also foreclosed defenses against arbitration's "fundamental attributes"-most notoriously, defenses against class waivers. ${ }^{27}$ Yet despite these profound limitations on contract defenses, the Court continues to insist that the Section 2 saving clause is alive, and that arbitration provisions are still subject to "generally applicable contract defenses." ${ }^{28}$ This is false. ${ }^{29}$

These developments only have practical effect to the extent that contract parties agree to arbitrate their disputes. Part II presents new evidence on the pervasiveness of employment arbitration. I use machine-learning protocols to analyze the text of millions of filings with the Securities and Exchange Commission and create a database of nearly 800,000 contracts formed by public companies. These contracts cover executive employment,

23 See infra Part I (discussing Prima Paint Corp. v. Flood \& Conklin Mfg. Co., 388 U.S. 395 (1967)). Prima Paint expressly states that its holding, though inspired by a Second Circuit opinion that argues toward the existence of a "national substantive law," was based solely on the text of the FAA. 388 U.S. at $399-400$.

24465 U.S. 1 (1984)

25 Many scholars have criticized Southland's application of the FAA to state courts. See, e.g., IAN R. Macneil et al., Federal Arbitration Law: Agreements, Awards, and Remedies Under the FEDERAL ARBITRATION ACT (1994); Edward Brunet, Toward Changing Models of Securities Arbitration, 62 Brook. L. Rev. 1459, 1469 (1996); Paul D. Carrington \& Paul H. Haagen, Contract and Jurisdiction, 1996 SuP. Cт. ReV. 331; Stephen L. Hayford \& Alan R. Palmiter, Arbitration Federalism: A State Role in Commercial Arbitration, 54 FLA. L. REV. 175 (2002); David S. Schwartz, Correcting Federalism Mistakes in Statutory Interpretation: The Supreme Court and the Federal Arbitration Act, 67 LAW \& CONTEMP. PROBS. 5 (2004). For a summary of this literature, see Christopher R. Drahozal, Federal Arbitration Act Preemption, 79 IND. L.J. 393, 400 n.57 (2004). For a notable exception to this wave of criticism, see Christopher R. Drahozal, In Defense of Southland: Reexamining the Legislative History of the Federal Arbitration Act, 78 Notre DAme L. Rev. 101 (2002).

269 U.S.C. $§ 2$ (2012).

27 See Epic Sys. Corp. v. Lewis, 138 S. Ct. 1612 (2018) (finding that an agreement to arbitrate employment disputes individually does not bar employees from engaging in "concerted activities" and therefore does not violate the National Labor Relations Act); AT\&T Mobility LLC v. Concepcion, 563 U.S. 333, 341-44 (2011) (holding that Section 2 preempts California's Discover Bank test, under which class action waivers in consumer contracts are unconscionable).

28 Concepcion, 563 U.S. at 339.

29 See infra Section I.C. 
credit agreements, joint ventures, purchases, and others. I show that employment contracts are by far the most likely to include a mandatory arbitration provision, and further that the difference between employment contracts and all others has been stable for the last twenty years. The data confirm what most have suspected: Employment arbitration is pervasive and here to stay.

Finally, Part III offers a new strategy to states for regulating employment arbitration. The question is, How can states enforce mandatory laws in contract actions when federal arbitration policy enables employers to opt out? The answer is simple: They cannot. Therefore, states should not rely on contract enforcement (or nonenforcement) to advance public policy. Instead, they should deter parties from forming contracts that would undermine state policy.

I offer two examples of how states can deploy this strategy. The first comes from employment covenants not to compete. Some states void postemployment covenants not to compete, but parties circumvent this by agreeing to arbitrate disputes under a more permissive law (as in Nitro-Lift, above). But instead of merely voiding noncompetes, states should offer employees whistleblower rewards (financed by employers) for notifying state authorities that their employer subjects employees to noncompetes. ${ }^{30}$ The employee may demonstrate this, for example, by showing that their own employment contract includes a noncompete. This policy would discourage employers and employees from forming, performing, or arbitrating noncompetes. Crucially, this policy would not be preempted by federal arbitration law because it does not regulate (let alone prohibit) arbitration.

The second example comes from the arbitration of civil rights claims. States and the public have an interest in ensuring certain procedural protections for employees pursuing these claims. Confidentiality in arbitration proceedings prevents a state from knowing whether these protections are in fact provided, or indeed whether civil rights are meaningfully enforced. Federal law would preempt any direct effort by states to prevent arbitration of any class of disputes. The strategy, therefore, is not to prohibit arbitration but instead to incentivize employers to give employees the option to litigate or arbitrate. States can do this by adopting an overinclusive policy: a blanket prohibition on civil rights as a subject matter for employment contracts. The prohibition could alternatively be for specific classes of civil rights disputes, such as sexual harassment claims. A subject

${ }^{30}$ In response to Concepcion (under which courts must enforce class action waivers), Professor Janet Alexander similarly argues that states can use qui tam actions to effectively recreate small-claims class actions. Janet Cooper Alexander, To Skin a Cat: Qui Tam Actions as a State Legislative Response to Concepcion, 46 U. Mich. J.L. REFORM 1203 (2013). 
matter prohibition, when again coupled with whistleblower rewards, can be structured to effectively grant employees the option to proceed (or not) to arbitration after a dispute arises.

Finally, it is worth emphasizing what this Article does and does not do. This Article does not argue in favor of or against arbitration per se as a dispute resolution system. Indeed, it does not even summarize the usual arguments. These arguments, as well as the relative merits of each state's policies, are orthogonal to the objectives of this Article. Rather, the objective of this Article is to diagnose a fundamental problem in contract enforcement - and then to offer one solution. The problem is that federal arbitration law prevents a state from ensuring that its laws are enforced in contract actions. The solution is that states should forget about contract enforcement and shift their focus to deterring contract formation.

\section{How STATES LOST CONTROL OVER CONTRACT ENFORCEMENT}

In this Part, I begin by showing how U.S. Supreme Court precedent immunized agreements to arbitrate from virtually all plausible contract defenses. I identify the origins of the Supreme Court's "national policy favoring arbitration," which forms the basis of most modern FAA cases. I then briefly consider the Court's treatment of the enforceability of arbitration awards. I conclude by identifying a possible limiting principle to the otherwise seemingly unlimited ability of private parties to use arbitration to evade mandatory state law.

\section{A. The Supreme Court's Position}

It is self-evident that the Federal Arbitration Act provides some circumstances under which a court may refuse to enforce an arbitration agreement. This is because Section 2 provides that, in almost ${ }^{31}$ all contracts "involving commerce," a written agreement to arbitrate "shall be valid, irrevocable, and enforceable, save upon such grounds as exist at law or in equity for the revocation of any contract." 32

The Supreme Court seemingly agrees. On several occasions, it has held that arbitration provisions are subject to standard contract defenses raised by private parties. Under the saving clause of Section 2, it claims, "generally applicable contract defenses, such as fraud, duress, or unconscionability, may be applied to invalidate arbitration agreements." ${ }^{33}$ The Court has also

\footnotetext{
31 See 9 U.S.C. $\$ 1$ (providing exceptions).

32 Id. $\S 2$.

33 Doctor's Assocs., Inc. v. Casarotto, 517 U.S. 681, 686-87 (1996) (citing Allied-Bruce Terminix Cos. v. Dobson, 513 U.S. 265, 281 (1995); Rodriguez de Quijas v. Shearson/Am. Express, Inc., 490 U.S.
} 
assured state lawmakers that the saving clause "gives States a method for protecting consumers against unfair pressure to agree to a contract with an unwanted arbitration provision." ${ }^{34}$ Moreover, it permits states to "regulate contracts, including arbitration clauses, under general contract law principles. ${ }^{\prime 35}$

But this is false. The Supreme Court says one thing when it has in fact done another. Over the last fifty years, the Court has foreclosed nearly every plausible circumstance under which private parties may raise a "generally applicable contract defense[]"36 or states "may regulate... arbitration clauses." ${ }^{37}$ Simply put, the saving clause of Section 2 has no bite. The rest of this Part investigates this claim in detail.

\section{B. The "National Policy Favoring Arbitration"}

\section{Dubious Origins}

The core of the Supreme Court's arbitration jurisprudence lies not in the federal statute, but in the "national policy favoring arbitration." 38 This policy is cited as a foundational basis for nearly every FAA decision since the mid-1980s ${ }^{39}$ But what is this policy? And where does it come from?

The Court's first reference to the policy-or rather its first reference to the idea that it exists - appeared in 1967 in Prima Paint Corp. v. Flood \& Conklin Manufacturing Co. ${ }^{40}$ forty years after the enactment of the FAA. ${ }^{41}$ The plaintiff, Prima Paint, had purchased Flood \& Conklin's (F\&C's) paint

\footnotetext{
477, 483-84 (1989); and Shearson/Am. Express Inc. v. McMahon, 482 U.S. 220, 226 (1987)); see also Perry v. Thomas, 482 U.S. 483, 492 n.9 (1987).

34 Allied-Bruce Terminix Cos., 513 U.S. at 281.

35 Id.

${ }^{36}$ Doctor's Assocs., 517 U.S. at 687.

37 Allied-Bruce Terminix Cos., 513 U.S. at 281. After surveying the case law and how it would apply to the most common contract defenses in Section I.C, I identify only one plausible contract defense that, if applied to one specific circumstance, might trigger the saving clause: $A$ actually knows that $B$ would never agree to arbitrate; $A$ tells $B$ that the contract does not include an arbitration provision (when in fact $A$ knows that it does); $B$, relying on this misrepresentation, manifests assent. This is not a meaningful limitation because it does not stop parties from intentionally escaping mandatory contract law. See below.

38 Southland Corp. v. Keating, 465 U.S. 1, 10 (1984).

39 See, e.g., Nitro-Lift Techs., L.L.C. v. Howard, 568 U.S. 17, 17 (2012); Preston v. Ferrer, 552 U.S. 346, 353 (2008) (quoting Southland, 465 U.S. at 10). The Supreme Court's deferential approach to arbitration predates the FAA. As early as 1854 , it asserted that, when reviewing arbitral awards, "[e]very presumption is in favor of the validity of the award" and that a court required more than mere error in fact or law, but an egregious procedural misconduct "such as corruption in the arbitrator, or gross mistake." Burchell v. Marsh, 58 U.S. 344, 349-51 (1854).

40388 U.S. 395 (1967).

${ }^{41}$ United States Arbitration Act, ch. 213, 43 Stat. 883 (1925) (codified as amended at 9 U.S.C. $\S \S 1-$ 14 (2012)), available at http://legisworks.org/sal/43/stats/STATUTE-43-Pg883.pdf [https://perma.cc/ THJ2-NV48].
} 
business and customer lists. ${ }^{42}$ It also secured ongoing consulting services from F\&C, along with a promise that F\&C not compete with Prima Paint in the painting business. ${ }^{43}$ However, one week after making this promise, and to the surprise of Prima Paint, F\&C filed for bankruptcy. ${ }^{44}$ Thus, Prima Paint would obtain F\&C's business and customer lists, but not its consulting services. ${ }^{45}$ Worst of all, F\&C's promise not to compete turned out to be worthless, as there was now no $\mathrm{F} \& \mathrm{C}$ to speak of. ${ }^{46}$

Prima Paint filed suit for fraud in the inducement, claiming that $\mathrm{F} \& \mathrm{C}$ had knowingly misrepresented its financial position so that it could "sell" the worthless noncompete and consulting retainer. ${ }^{47} \mathrm{~F} \& \mathrm{C}$ moved to compel arbitration under its contract's broad arbitration provision. ${ }^{48}$ The issue before the U.S. Supreme Court was whether a claim for fraud in the inducement must be sent to the arbitrator. ${ }^{49}$

The majority concluded yes: the FAA, it reasoned, provides the "explicit answer." ${ }^{50}$ Section 4 provides that a court shall compel arbitration "upon being satisfied that the making of the agreement for arbitration ... is not in issue." ${ }^{51}$ In this case, plaintiff's claim was for fraud in the inducement of the contract as a whole - not for fraud in the inducement of the agreement to arbitrate specifically. ${ }^{52}$ Therefore, as far as the Court was concerned, the "making of the agreement for arbitration" was not at issue, and the Court sent the case to an arbitrator. ${ }^{53}$ Under this reasoning, any formation defense concerning the contract as a whole must be sent to an arbitrator.

The problem with this reasoning is that fraudulent inducement of the contract could imply fraudulent inducement of each of its provisions. Section 4 is therefore ambiguous at best. It does not provide an "explicit answer." 54 It only compels another question: whether fraud in the whole implies fraud in each part. Nevertheless, the Court admitted no such ambiguity and held that a claim for fraud in the inducement must be sent to an arbitrator.

42 Prima Paint Corp., 388 U.S. at 397

${ }^{43} I d$.

${ }^{44} I d$. at 398 .

45 See id.

46 See id.

47 Id.

48 Id. at 399.

${ }^{49}$ Id. at 396-97.

50 Id. at 403.

519 U.S.C. $\S 4$ (2012).

52 Prima Paint Corp., 388 U.S. at 402.

53 Id. at 403-04, 406-07.

${ }^{54} \mathrm{Id}$. at 403. 
Prima Paint wiped out an entire class of circumstances under which a court could cite the saving clause of Section 2 to refuse to enforce an arbitration agreement. Logically, we may partition all such circumstances into two classes of cases: (1) cases in which there are "grounds . . a law or in equity" 55 to revoke the entire contract and (2) cases in which there are "grounds... at law or in equity" to revoke the arbitration provision specifically. Prima Paint rules out the first.

The Prima Paint majority does not mention any national arbitration policy, let alone one that could favor or disfavor arbitration. For that, we must turn to the dissent.

Justice Hugo Black's dissent took issue with much of the majority's opinion. His principal criticism ${ }^{56}$ concerned the majority's express reliance on the Second Circuit's decision in Robert Lawrence Co. v. Devonshire Fabrics, Inc. ${ }^{57}$ Ten years prior, Robert Lawrence had reached a similar conclusion, that formation of an agreement to arbitrate is, for the purposes of Section 2 of the FAA, treated separately from formation of the contract. ${ }^{58}$ This has since been dubbed the "separability rule." 59

What the Prima Paint majority failed to mention, argued Justice Black, was that Robert Lawrence was not decided on the basis of Section $4 .{ }^{60}$ Rather, the Second Circuit based its opinion on "a reasonably clear legislative intent to create a new body of substantive law relative to arbitration agreements," ${ }_{61}$ one that "encompasses questions of interpretation and construction as well as questions of validity, revocability and enforceability of arbitration agreements affecting interstate commerce or maritime affairs." ${ }^{2}$

But the intervening juggernaut of Erie Railroad Co. v. Tompkins, ${ }^{63}$ decided after the FAA but before Robert Lawrence, should have compelled the Second Circuit to reach the opposite conclusion. ${ }^{64}$ Erie would require the Second Circuit to apply New York law. At the time, New York law did not

\footnotetext{
559 U.S.C. $\$ 2$.

56 See Prima Paint Corp., 388 U.S. at 421-22 (Black, J., dissenting).

57271 F.2d 402 (2d Cir. 1959).

58 Id. at $409-10$.

59 Stephen J. Ware, Alternative Dispute Resolution $\$ 2.24$ (2001). For critiques of the separability rule, see Richard C. Reuben, First Options, Consent to Arbitration, and the Demise of Separability: Restoring Access to Justice for Contracts with Arbitration Provisions, 56 SMU L. REv. 819, 841-48 (2003).

${ }^{60}$ Prima Paint Corp., 388 U.S. at 421 (Black, J., dissenting).

61 Robert Lawrence Co., 271 F.2d at 404.

62 Prima Paint Corp., 388 U.S. at 421 (Black, J., dissenting) (quoting Robert Lawrence Co., 271 F.2d at 409).

63304 U.S. 64 (1938).

64 See Prima Paint Corp., 388 U.S. at 424-25 (Black, J., dissenting).
} 
recognize any "separability rule." On the contrary, " $[u]$ nder New York law ... general allegations of fraud in the inducement would ... put in issue the making of the arbitration clause," thereby failing Section 4's condition and permitting a court to refuse to compel arbitration. ${ }^{65}$ The Second Circuit in Robert Lawrence ignored this; contravening Erie and New York law, it fashioned the separability rule as a doctrine within the new "body of federal substantive law." ${ }^{66}$ It did so, wrote Justice Black, "not because $\S 4$ provided this rule as an 'explicit answer,' not because [it] looked to the intention of the parties, but because of [its] notion that the separability rule would further a 'liberal policy of promoting arbitration." ${ }^{67}$ This statement-Justice Black's quotation of the Second Circuit's appeal to a "liberal policy of promoting arbitration"-is the first instance in which the Supreme Court references the idea that there exists a policy favoring arbitration.

Justice Black had argued in dissent that no such policy exists, but Robert Lawrence was adamant that it did. Robert Lawrence insisted that such a policy had been "consistently reiterated by the federal courts." 68 To support this assertion, Robert Lawrence cited several cases from the Second and Eighth Circuits. ${ }^{69}$ It also cited an early FAA decision of the Supreme Court, Shanferoke Coal \& Supply Corp. v. Westchester Service Corp. ${ }^{70}$ which upheld a motion to stay proceedings pending arbitration. But this last citation is inapposite. Shanferoke is a straightforward application of the FAA. It neither refers to nor hints at a latent national policy, nor does it offer guidance on interpreting the FAA.

In any event, here in the dissent to Prima Paint lie the dubious origins of the national policy favoring arbitration-dubious because even the majority dismisses it. Though the Prima Paint majority expressly endorses Robert Lawrence's holding, it also expressly disavows its rationale, ${ }^{71}$ instead

65 Id. at 421.

66 Id. at 422.

67 Id. at 421. According to the Second Circuit, "doubts as to the construction of the [FAA] ought to be resolved in line with its liberal policy of promoting arbitration." Robert Lawrence Co., 271 F.2d at 410 .

68 Robert Lawrence Co., 271 F.2d at 410.

69 Signal-Stat Corp. v. Local 475, United Elec., Radio \& Mach. Workers of Am., 235 F.2d 298 (2d Cir. 1956), cert. denied, 354 U.S. 911 (1957); Kulukundis Shipping Co., S/A v. Amtorg Trading Corp., 126 F.2d 978 (2d Cir. 1942); Wabash R. Co. v. Am. Refrigerator Transit Co., 7 F.2d 335, 351 (8th Cir. 1925), cert. denied, 270 U.S. 643 (1926).

70293 U.S. 449 (1935).

71 The majority noted that under Robert Lawrence,

a claim of fraud in the inducement of the contract generally - as opposed to the arbitration clause itself - is for the arbitrators and not for the courts; and that this rule-one of "national substantive law"-governs even in the face of a contrary state rule. We agree, albeit for somewhat different reasons, and we affirm the decision below. 
choosing to ground its holding in the text of the FAA. ${ }^{72}$ Thus, the Supreme Court's original position on the existence and implications of a "national policy favoring arbitration" was either "no comment" (per the majority) or "nonexistent" (per the dissent).

But the Supreme Court would later see things differently. Fifteen years after Prima Paint, the Court made its second reference to the "national policy" - and on very different terms. We find this reference in Moses $H$. Cone Memorial Hospital v. Mercury Construction Corp.,${ }^{73}$ an abstention case that only tangentially implicates the FAA. In Moses, the Court remarked in dicta that Prima Paint established that "Section 2 is a congressional declaration of a liberal federal policy favoring arbitration agreements, notwithstanding any state substantive or procedural policies to the contrary." 74

This is wrong. ${ }^{75}$ The "liberal federal policy" language comes from the dissent. The Prima Paint majority expressly disavows such arguments. ${ }^{76}$ In fact, in its sole reference to any policy, purpose, or congressional intent, the Prima Paint majority conveys the opposite sentiment: "[T]he purpose of [the FAA]," it wrote, "was to make arbitration agreements as enforceable as other contracts, but not more so." "77 It further expressly states that it does not rely on Robert Lawrence's reasoning on the policy goals of the FAA, and that its holding is based only on the "plain meaning" "78 interpretation of Sections 3 and $4 .{ }^{79}$

Prima Paint Corp. v. Flood \& Conklin Mfg. Co., 388 U.S. 395, 400 (1967) (footnote omitted).

72 See id. ("We agree [with the decision below], albeit for somewhat different reasons, and we affirm the decision below.") (emphasis added).

73460 U.S. 1 (1983).

74 Id. at 24 . It further noted that "[t]he effect of the section is to create a body of federal substantive law of arbitrability" and that "any doubts concerning the scope of arbitrable issues should be resolved in favor of arbitration, whether the problem at hand is the construction of the contract language itself or an allegation of waiver, delay, or a like defense to arbitrability." Id. at 24-25.

75 Previous scholarship on Moses has remarked that "[t]he so-called policy favoring arbitration appears to be one created by the judiciary out of whole cloth." Margaret L. Moses, Statutory Misconstruction: How the Supreme Court Created a Federal Arbitration Law Never Enacted by Congress, 34 Fla. ST. U. L. REV. 99, 123 (2006). I, however, attribute its creation to an embarrassing error on the part of the Moses court: the Moses court must have read the Prima Paint dissent's discussion of Robert Lawrence and mistaken it for the Prima Paint majority's own reasoning. See below.

76 See Prima Paint Corp., 388 U.S. at 399-400.

77 Id. at 404 n.12; see also Epic Sys. Corp. v. Lewis, 138 S. Ct. 1612, 1645 (2018) (Ginsburg, J., dissenting) (quoting the same). On this point, the dissent agreed: "The avowed purpose of the Act was to place arbitration agreements "upon the same footing as other contracts." Prima Paint Corp., 388 U.S. at 423 (Black, J., dissenting) (quoting H.R. REP. No. 96, 68th Cong., 1st Sess. (1924)).

78 Prima Paint Corp., 388 U.S. at 404.

79 Id. at 399-400 (agreeing with the outcome of Robert Lawrence, but for different reasons); id. at 403-04 (interpreting Section 4). 
The Moses court made an embarrassing mistake. It must have read Justice Black's critique of Robert Lawrence and then mistakenly presumed he was critiquing the Prima Paint majority. Then again, the Moses dicta was just that - dicta. It had no bearing on the case at hand. It might have been forgotten.

\section{Expansion to State Court}

Moses was not forgotten. The third and most consequential reference to the national policy is found in the 1984 case of Southland Corp. v. Keating. ${ }^{80}$ The majority would base its entire argument on a citation to the national policy statement from Moses. This case would also mark the beginning of the end of mandatory contract law.

Southland issued two holdings, one general, the other specific. The general holding is that the FAA applies not just in federal court but also in state court. ${ }^{81}$ The specific holding is that the saving clause did not apply to the arbitration provision at issue. ${ }^{82}$ The specific holding, and particularly the process by which it was reached, is what marks the beginning of the end of mandatory contract law. Yet the specific holding is also the least remembered. Indeed, neither the majority nor the dissent paid any attention to it. I next consider each holding in turn.

Southland originated in state court, and so the threshold question was whether the FAA applied ${ }^{83}$ First, consider Justice Sandra Day O'Connor's answer. Writing in dissent, Justice O'Connor argued that the FAA's direct references to federal courts, along with the conspicuous absence of any reference to state courts, were sufficient to conclude that the FAA applied only in the former. ${ }^{84}$ Section 4 provides that a party aggrieved by another's refusal to arbitrate "may petition any United States district court ... for an order directing that such arbitration proceed in the manner provided for in such agreement." 85

Section 3 further provides that

[i]f any suit or proceeding be brought in any of the courts of the United States upon any issue referable to arbitration ... the court ... shall on application of

\footnotetext{
80465 U.S. 1, 10 (1984).

81 Id. at $14-15$.

82 Id. at 15 (" $[\mathrm{I}] \mathrm{t}$ is clear beyond question that if this suit had been brought as a diversity action in a federal district court, the arbitration clause would have been enforceable.”).

83 If it did, then two subsequent questions would emerge: Did Section 2 oblige the state court to enforce the arbitration provision at issue? And did Section 4 further oblige the state court to specifically enforce the arbitration provision at issue? These questions were never directly posed by the Court. Instead, the Court declared that the answers to these questions were "clear beyond question." Id.

84 Id. at 22-23 (O’Connor, J., dissenting).

85 Id. at 22 (quoting 9 U.S.C. $§ 4)$ ).
} 
one of the parties stay the trial of the action until such arbitration has been had in accordance with the terms of the agreement. ${ }^{86}$

In Justice O'Connor's view, this was sufficient to hold that the FAA applies only in federal court. The reasoning, it would seem, is self-evident. The statute does not say "court" or "any court." It says "United States district court." For Justice O'Connor, this was as plain as plain meaning could be. ${ }^{87}$

But the majority held otherwise. The majority did not address or even acknowledge the references to "United States courts" in Sections 3 and 4. The sole basis for its opinion is a citation to Moses for the proposition that "[i]n enacting $\S 2$ of the federal Act, Congress declared a national policy favoring arbitration." 88 This policy, it held, was sufficient to conclude that the FAA - in its entirety - applies to state courts. ${ }^{89}$ Thus, what began as an embarrassing mistake in Moses became the foundation for the Court's arbitration jurisprudence.

\section{States Strike Back}

Southland is the watershed arbitration case. It expanded the FAA's jurisdictional scope-and therefore the extent to which parties could specifically enforce an arbitration provision. Before Southland, a contract needed an independent jurisdictional hook to make it into federal court and trigger the application of the FAA's specific performance remedy. Typically, the hook was diversity. ${ }^{90}$ An arbitration provision, by itself, was not-and

\footnotetext{
86 Id. (quoting 9 U.S.C. $§ 3$ ).

87 Id. at 29. Justice O'Connor also cites Supreme Court precedent. Id. at 30. For example, the holding in Prima Paint expressly applied to federal courts. Prima Paint Corp. v. Flood \& Conklin Mfg. Co., 388 U.S. 395, 404 (1967) ("We hold, therefore, that in passing upon a [Section 3] application for a stay while the parties arbitrate, a federal court may consider only issues relating to the making and performance of the agreement to arbitrate." (emphasis added)).

88 Southland, 465 U.S. at 10 (majority opinion).

89 Id. The majority also offered a quasi-textual (and nonsensical) argument: Congress could have directed federal courts to specifically enforce all arbitration provisions, not just those in contracts "involving commerce." Because Congress limited the Act to contracts within the reach of the Commerce Clause, it must have intended the Act to apply in both federal and state courts. $I d$. at 15 . This is nonsense because Congress could have intended both. That is, Congress could have intended the Act to apply only to contracts that (1) are litigated in federal courts and (2) involve commerce. Justice Thomas similarly observed that the Section 2 argument was, in his words, the Southland majority's only "real response" to Sections 3 and 4 of the statute. Allied-Bruce Terminix Cos. v. Dobson, 513 U.S. 265, 292 (1995).
}

Yet Congress might well have thought that even if it could have called upon federal courts to enforce arbitration agreements in every single case that came before them, there was no federal interest in doing so unless interstate commerce or maritime transactions were involved. This conclusion is far more plausible.

Id. Indeed, there would be no federal interest in disturbing the jurisdiction of state courts over noncommercial contracts, such as agreements under family law.

90 Until 2009, it was not clear whether a court may alternatively rely on the federal nature of the underlying dispute as a basis for subject matter jurisdiction. In Vaden v. Discover Bank, 556 U.S. 49, 53 
still is not-sufficient grounds for federal subject matter jurisdiction. ${ }^{91}$ After Southland, no such hook was needed. Specific performance was now available in state court. Parties to any contract "involving commerce" could now specifically enforce a valid arbitration provision.

Southland is also a turning point for the Supreme Court's docket. Table 1 shows that the volume of its arbitration cases increased significantly, while Figure 1 shows that arbitration-related disputes continue to consume an ever-increasing share of the Court's caseload. ${ }^{92}$

Some of these cases were pushback, if not outright rebellion, by state supreme courts. These cases pushed back against the U.S. Supreme Court's ever-expanding theory of the scope of FAA preemption. Some states simply ignored unambiguous U.S. Supreme Court precedent. ${ }^{93}$ Other states were openly hostile. Southland, wrote one state supreme court justice, "bludgeoned the [FAA] .... If the liberties in statutory construction taken by the Supreme Court in Southland hint at the horizons of American jurisprudence, I shudder to think what atrocities might follow."94 Southland's reasoning, wrote another state supreme court justice, was "tendentious,"

(2009), the Supreme Court decided that it could; see also Imre S. Szalai, The Federal Arbitration Act and the Jurisdiction of the Federal Courts, 12 HARV. NEGOT. L. REV 319, 343-47 (2007) (analyzing arguments for and against such a basis).

91 Section 4 provides that

[a] party aggrieved by the alleged failure, neglect, or refusal of another to arbitrate under a written agreement for arbitration may petition any United States district court which, save for such agreement, would have jurisdiction under title $28 \ldots$ for an order directing that such arbitration proceed in the manner provided for in such agreement.

9 U.S.C. $\$ 4$ (2012) (emphasis added). Southland did not change this. Southland, 465 U.S. at 15 n.9; see also id. at 24 .

92 The data come from the Supreme Court Database. See Harold J. Spaeth et al., 2017 Supreme Court Database, Version 2017 Release 01, http://supremecourtdatabase.org [https://perma.cc/UD9P-8G5G]. A case is defined as "arbitration-related" if the database identifies its sole issue as "arbitration." Qualitatively similar results are obtained if one also counts cases for which "arbitration" is one of the case's many issues.

${ }^{93}$ For example, in one case from Alabama, the state court reversed a motion to compel arbitration on the rationale that debt contracts did not fall under the Commerce Clause. Alafabco, Inc. v. Citizens Bank, 872 So. 2d 798, 808 (Ala. 2002), rev'd, 539 U.S. 52 (2003). In another case from Florida, KPMG LLP v. Cocchi, 51 So. 3d 1165, 1168 (Fla. Dist. Ct. App. 2010), vacated, 565 U.S. 18 (2011), the state court held that when a contract includes both arbitrable and non-arbitrable claims, the FAA permits courts to refuse to compel arbitration of any claim. This directly violated a categorical rule issued by the U.S. Supreme Court in Dean Witter Reynolds Inc. v. Byrd, 470 U.S. 213, 244 (1985) (requiring a court to compel arbitration of the arbitrable claims).

94 Ex parte Ala. Oxygen Co., 452 So. 2d 860, 861 (Ala. 1984) (Embry, J., dissenting). In the same Term that Southland was decided, the U.S. Supreme Court vacated an Alabama Supreme Court decision that directly conflicted with its holding. York Int'l v. Ala. Oxygen Co., 465 U.S. 1016 (1984). On remand, the Alabama Supreme Court duly reversed its own holding. Ex parte Ala. Oxygen Co., 452 So. $2 \mathrm{~d}$ at 861. 
"created from whole cloth," and "[c]ontrary to the intended purpose of the Federal Arbitration Act." 95

In reply to these and other state court mutinies, the U.S. Supreme Court issued its own set of return volleys: "The Supreme Court of Appeals of West Virginia ... misrea[d] and disregard[ed] the precedents of this Court." ${ }^{96}$ "The Supreme Court of Alabama was . . misguided." ${ }^{97}$ Similar rebukes can be found against Oklahoma ${ }^{98}$ and Montana. ${ }^{99}$ These rebukes quelled some states, while further emboldening others, including both state courts ${ }^{100}$ and state legislatures. ${ }^{101}$

TABLE 1: U.S. SUPREME COURT CASELOAD

\begin{tabular}{|l|c|c|}
\hline & Pre-Southland & Post-Southland \\
\hline $\begin{array}{l}\text { Number of arbitration- } \\
\text { related cases }\end{array}$ & 5 & 20 \\
\hline $\begin{array}{l}\text { Percent of total cases that } \\
\text { are arbitration-related }\end{array}$ & $0.08 \%$ & $0.55 \%$ \\
\hline Years & $1946-1983$ & $1985-2016$ \\
\hline
\end{tabular}

Source: SuPREME COURT DATABASE.

95 Brown ex rel. Brown v. Genesis Healthcare Corp., 724 S.E.2d 250, 278-79 (W. Va. 2011), vacated sub nom. Marmet Health Care Ctr., Inc. v. Brown, 565 U.S. 530 (2012).

96 Marmet Health Care Ctr., 565 U.S. at 531.

97 Citizens Bank v. Alafabco, Inc., 539 U.S. 52, 56 (2003).

98 Nitro-Lift Techs., L.L.C. v. Howard, 568 U.S. 17, 20 (2012) (“The Oklahoma Supreme Court's decision disregards this Court's precedents on the FAA.").

99 Doctor's Assocs., Inc. v. Casarotto, 517 U.S. 681, 688 (1996).

${ }^{100}$ Montana, for instance, continues to ignore U.S. Supreme Court precedent in its arbitration decisions. See, e.g., Woodruff v. Bretz, Inc., 218 P.3d 486, 494 (Mont. 2009) (invalidating all arbitration provisions in contracts of adhesion if they are outside a party's reasonable expectations).

101 Even after Southland (and perhaps because of it), many states enacted laws regulating arbitration. Some states continue to maintain laws that would clearly be preempted under Supreme Court precedent. Georgia, for example, requires that employees specifically initial the arbitration clause. GA. CODE ANN. $\S 9-9-2(c)(9)$ (2018). California prohibits arbitration for claims of unpaid wages. CAL. LAB. CODE $§ 229$ (West 2018). A Kentucky law mirroring the FAA previously excluded all employment agreements. KY. Rev. StAt. Ann. $\$ 417.050$ (West 2018). But this was preempted by Circuit City Stores, Inc. v. Adams, 532 U.S. 105 (2001). See In re Transp. Assocs., Inc., 263 B.R. 531, 533-34 (Bankr. W.D. Ky. 2001); see also MONT. CODE ANN. § 27-5-114 (2017) (requiring arbitration agreements to be on the first page of a contract) (preempted in Doctor's Assocs., 517 U.S. at 681, and section (4) was subsequently repealed); S.C. CodE ANN. § 15-48-10 (2018) (similar). 
N ORTHW ESTER N UNIVERS ITY LA W REVIEW

Figure 1: ARBitRATION-RELATED CASElOAD OVER TIME

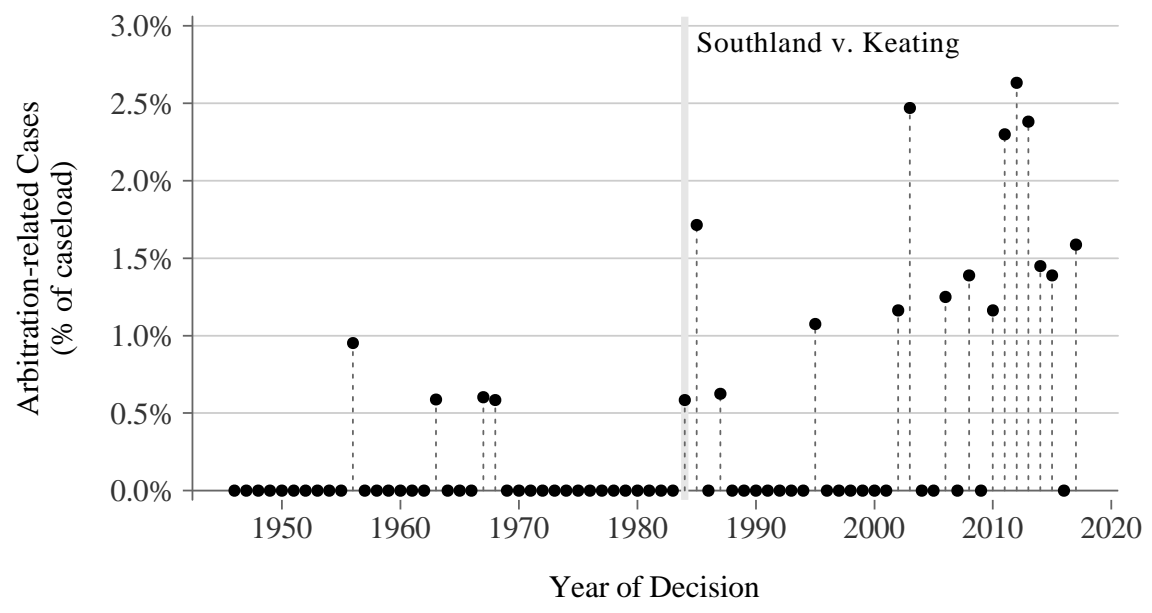

C. The End of Contract Defenses

\section{The Key Move}

Southland's general holding - applying the FAA to state courts- has been roundly criticized by scholars. ${ }^{102}$ But it is its second holding that has led to the unraveling of mandatory contract law.

The second holding tacitly placed a new limit on the saving clause of Section 2. Recall that Prima Paint rules out cases for which there exist "grounds . . . at law or in equity" 103 to revoke the entire contract. Thus, even before Southland, a court could refuse to enforce an agreement to arbitrate only if there were "grounds . . . at law or in equity" to revoke the arbitration provision specifically.

The arbitration provision at issue in Southland came from the standard franchise agreement of Southland Corporation (the erstwhile corporate name of 7-Eleven). The California Supreme Court, construing a section of the California Franchise Investment Law, ${ }^{104}$ held that Southland's arbitration provision was unenforceable as a matter of public policy. It reasoned that a U.S. Supreme Court case from thirty years prior, Wilko v. Swan, ${ }^{105}$ compelled this conclusion because Wilko had similarly construed an identically worded

102 See supra note 25.

1039 U.S.C. $\$ 2$ (2012).

104 See CAL. CORP. CODE $\$ 31512$ (2018) ("Any condition, stipulation or provision purporting to bind any person acquiring any franchise to waive compliance with any provision of this law or any rule or order hereunder is void.").

105346 U.S. 427 (1953). 
federal statute. ${ }^{106}$ Thus, to specifically enforce the arbitration provision, the Southland majority's opinion needed not only to hold that the FAA applies in state court but also that it preempts the California Supreme Court's interpretation of its statute as "grounds as exist at law or in equity" upon which to refuse enforcement. ${ }^{107}$

The Court so held. The body of the majority opinion provides no reason for this holding. ${ }^{108}$ But a final footnote offers a hint:

[A] party may assert general contract defenses such as fraud to avoid enforcement of an arbitration agreement. We conclude, however, that the defense to arbitration found in the California Franchise Investment Law is not a ground that exists at law or in equity "for the revocation of any contract" but merely a ground that exists for the revocation of arbitration provisions in contracts subject to the California Franchise Investment Law. ${ }^{109}$

The idea, it seems, is that state law cannot single out arbitration. The Supreme Court slowly refined this idea over time. The first refinement appeared in Perry v. Thomas ${ }^{110}$ :

[S]tate law, whether of legislative or judicial origin, is applicable [to the saving clause] if that law arose to govern issues concerning the validity, revocability, and enforceability of contracts generally.... [A] court [may not] rely on the uniqueness of an agreement to arbitrate as a basis for a state-law holding . . . .111

The idea then crystalized in AT\&T Mobility v. Concepcion"112: "[The] saving clause permits agreements to arbitrate to be invalidated by generally applicable contract defenses, such as fraud, duress, or unconscionability, but not by defenses that apply only to arbitration or that derive their meaning from the fact that an agreement to arbitrate is at issue." 113 The now-familiar refrain has appeared most recently in Epic Systems Corp. v. Lewis: "[T]he saving clause recognizes only defenses that apply to 'any' contract. In this

106 See Securities Act of 1933, 15 U.S.C. $\$ 77 n$ (2012). Four years after Southland, Wilko was overruled. Rodriguez de Quijas v. Shearson/Am. Exp. Inc., 490 U.S. 477 (1989).

1079 U.S.C. $\$ 2$ (2012).

108 In its sole reference to the second issue, the Court wrote only that "it is clear beyond question that if this suit had been brought as a diversity action in a federal district court, the arbitration clause would have been enforceable." Southland Corp. v. Keating, 465 U.S. 1, 15 (1984). The dissent, for its part, did not mention the Court's second holding.

109 Southland, 465 U.S. at 16 n.11 (quoting 9 U.S.C. § 2).

110482 U.S. 483 (1987).

111 Id. at 493 n.9 (emphasis omitted).

112563 U.S. 333 (2011); see also Jean R. Sternlight, Tsunami: AT\&T Mobility LLC v. Concepcion Impedes Access to Justice, 90 OR. L. REV. 703 (2012) (analyzing the implications of Concepcion).

113 Concepcion, 563 U.S. at 339 (emphasis added) (citing Doctor's Assocs., Inc. v. Casarotto, 517 U.S. 681, 687 (1996)) (quotations omitted). 
way the clause establishes a sort of 'equal-treatment' rule for arbitration contracts." 114

If one were to take these statements at face value, one might conclude that the Supreme Court has in fact adopted a position of neutrality or "equal treatment" with respect to arbitration. But while the logic of "general applicability" sounds neutral in theory, in practice it is not.

The problem is that when the Supreme Court applies this idea to actual cases, it mischaracterizes the nature of a "generally applicable" contract defense. What makes a contract defense "generally applicable"? The answer is not that, when applied, the argument advancing the defense eschews specificity or merely calls upon some general proposition like "pacta sunt servanda" (agreements must be kept). "General propositions do not decide concrete cases." 115 There is no such thing as a "general" contract argument. Rather, what makes a defense generally applicable is that the style of argument could apply to a diversity of exchanges. When applied to an actual case, a general defense necessarily derives its meaning from specific facts of that exchange. To argue a general defense such as unconscionability or fraud, one must attack a specific provision of the agreement, or a specific representation of one party, or a specific belief of one party, or a specific fact of the world - or some combination thereof. Thus, a generally applicable defense, while general in theory, is necessarily specific in application.

The Supreme Court's key move - the one that quietly annihilates a whole class of potential defenses - is that it characterizes a "generally applicable" defense as one that does not "derive [its] meaning from" a specific fact of arbitration. The move here is not to foreclose any contract defense. Instead, the move is to foreclose the application of any contract defense.

Consider two examples. Suppose one person compliments another's dancing performance. There is nothing inherently fraudulent about this specific fact. If, however, the compliment were disingenuous and made only to induce the receiver to purchase more dance lessons, then this compliment may become fraudulent within the context of that exchange. ${ }^{116}$ Similarly, suppose one party pays another $\$ 450$ in exchange for a promise to either perform some task or return the money. The promise to return the money is

114138 S. Ct. 1612, 1622 (2018) (quoting Kindred Nursing Ctrs. Ltd. P'ship v. Clark, 137 S. Ct. $1421,1426(2017))$.

115 Lochner v. New York, 198 U.S. 45, 76 (1905) (Holmes, J., dissenting).

116 See Vokes v. Arthur Murray, Inc., 212 So. 2d 906 (Fla. Dist. Ct. App. 1968) (holding that the defendant's statements misrepresenting the plaintiff's dancing abilities were actionable because the compliments induced the plaintiff to purchase more dance lessons); see also RESTATEMENT (SECOND) OF CONTRACTS §§ 168-69 (AM. LAW INST. 1981) (discussing when it is reasonable to rely on an assertion of opinion). 
enforceable - at least generally and in the abstract. But if the payment were a bribe in exchange for a political favor, then this otherwise innocuous promise to repay becomes unenforceable as a matter of public policy. ${ }^{117}$

The lesson of these two examples is simple. Terms or features of the bargaining process that are innocuous in isolation (such as compliments or promises to repay) may, within the context of a specific exchange, become fraudulent, or unconscionable, or against public policy.

The same applies to arbitration. Like a gratuitous compliment or a simple promise to repay, there is nothing inherently fraudulent or unconscionable about arbitration. In the context of a specific exchange, however, an otherwise innocuous arbitration provision may, like a compliment or promise to repay, become unconscionable or fraudulent. ${ }^{118}$

Imagine what would happen if the same limit that the Supreme Court applies to arbitration provisions were applied to the two examples above. That is, imagine that a party may raise a "generally applicable contract defense" - but only if the defense does not "derive its meaning" from the fact that either (1) a compliment or (2) a promise to repay is at issue. How could either case be argued? How could the victim of a fraudulently induced dancing lesson actually apply the formation defense of fraud in the inducement without reference to the compliment? She could not. Or how could a court refuse to enforce the bribery contract if federal law barred a public policy defense from "deriv[ing] its meaning" from the fact that a promise to repay is at issue? It could not. Thus, the Court's key moveforeclosing defenses that, when applied, reference any element of arbitration-prevents parties from applying "generally applicable" defenses.

117 See Sinnar v. Le Roy, 270 P.2d 800 (1954) (finding a contract void for illegality because it violated state laws about liquor licenses).

118 For example, in Ferguson v. Countrywide Credit Indus., Inc., 298 F.3d 778, 782-87 (9th Cir. 2002), the Ninth Circuit held that an employment contract's arbitration provision was unconscionable because supplemental provisions on fee shifting and the number of allowable depositions disproportionately impacted the employee. 
This limitation can be (and is) used to shut down common contract defenses, such as mistake, ${ }^{119}$ capacity, ${ }^{120}$ and duress. ${ }^{121}$

It would be a mistake to interpret the Court's neutral language as advancing neutral policy, one that merely treats arbitration provisions like any other, or, as the Southland court put it, one that honors the "congressional intent to place arbitration agreements "upon the same footing as other contracts." "122 Under Prima Paint, a court may only decide "issues relating

119 See, e.g., Masco Corp. v. Zurich Am. Ins. Co., 382 F.3d 624, 630 (6th Cir. 2004) (a claim for mutual mistake must be resolved by the arbitrator). It is not possible to mount a defense premised on mistake. A party would have to show not only that the nonexistence of the arbitration provision was a basic assumption upon which the contract was made but also that enforcing the arbitration provision would either (a) materially adversely affect her (if the mistake were mutual) or (b) lead to an "unconscionable" result (if the mistake were unilateral). RESTATEMENT (SECOND) OF CONTRACTS $\S \S 152-54$. Neither defense is permissible because it would require a specific holding that compelling arbitration would, in fact, materially adversely affect one of the parties, and therefore that the arbitral forum itself is somehow inadequate. Again, such a holding would necessarily "single out" features of the arbitral process. The Supreme Court has prohibited such reasoning. Kindred Nursing Ctrs., 137 S.Ct. at 1428 n.2.

120 A circuit split has emerged on whether the court or the arbitrator should resolve a dispute when one party raises a capacity defense. Compare Primerica Life Ins. Co. v. Brown, 304 F.3d 469, 471 (5th Cir. 2002) (the issue should be resolved by the arbitrator), with Spahr v. Secco, 330 F.3d 1266, 1286 (10th Cir. 2003) (the issue should be resolved by the court), and Rowan v. Brookdale Senior Living Cmtys., 2015 WL 9906264, at 4 (W.D. Mich. June 1, 2015) (same), aff'd, 647 F. App'x 607 (6th Cir. 2016). The Supreme Court has never heard a capacity case, but it would almost surely hold that such disputes must be sent to the arbitrator. Capacity applies to the formation of the contract in its entirety, not to the inclusion of any specific provision. See generally RESTATEMENT (SECOND) OF CONTRACTS $§ § 14$ (infancy), 15 (mental illness). The Court's rule in such instances is categorical: "[U]nless the challenge is to the arbitration clause itself, the issue of the contract's validity is considered by the arbitrator in the first instance." Buckeye Check Cashing, Inc. v. Cardegna, 546 U.S. 440, $445-46$ (2006). For the capacity defense to apply only to the arbitration clause, it must be that the agreement to arbitrate was formed separately. That is, it must be that a capable party formed a contract without an arbitration agreement, subsequently became incapable, and, while incapable, modified the existing contract with the arbitration agreement.

121 This defense is implausible. A claim that the contract was formed under physical duress or coercion goes to formation of the contract as a whole. RESTATEMENT (SECOND) OF CONTRACTS $§ 174$. Again, this defense would be sent to the arbitrator. Prima Paint Corp. v. Flood \& Conklin Mfg. Co., 388 U.S. 395, 400 (1967). Any other duress defense would require a showing that the aggrieved party assented only because of another's "improper threat," such as a crime or tort, and that the threat left the aggrieved party with "no reasonable alternative." RESTATEMENT (SECOND) OF CONTRACTS §§ 175(1) (improper threat by the counter-party), 175(2) (improper threat by a third party), 176 (defining an improper threat). But the "alternative" to arbitration is the public courts. Assessing the reasonableness of this alternative would require a comparison of arbitration and litigation, which in turn would rely on facts specific to arbitration. See, e.g., Austin Instrument, Inc. v. Loral Corp., 29 N.Y.2d 124 (1971) (on economic duress generally). Thus, we are again left with only one contrived possibility: Two parties form a valid contract without an arbitration provision; then one party physically compels the other to modify it by including an arbitration provision.

122 Southland Corp. v. Keating, 465 U.S. 1, 15, 16 n.11 (1984) (quoting H.R. REP. No. 96, 68th Cong., 1st Sess. (1924)); see also Prima Paint Corp., 388 U.S. at 423 (Black, J., dissenting) (also quoting H.R. REP. No. 96, 68th Cong., 1st Sess. (1924)). 
to the making and performance of the agreement to arbitrate." ${ }^{123}$ It must send any defense relating to the validity of the contract as a whole to an arbitrator. Yet under Southland and subsequent cases, a defense may not cite any specific feature of the arbitral forum or the arbitration provision at issue.

In summary, the saving clause of Section 2 of the FAA expressly provides grounds for refusing to enforce an arbitration provision. But, according to the Supreme Court, a defense that implicates the arbitration provision is barred, while a defense that does not implicate the arbitration provision is sent to the arbitrator. The Supreme Court has Catch 22-ed the saving clause out of existence.

\section{The End of State Policies}

In a separate opinion to Southland, concurring in part and dissenting in part, Justice John Paul Stevens anticipated how eliminating the saving clause would affect a state's public policy. ${ }^{124}$ Justice Stevens agreed with the majority on the first issue: even if Congress intended that the FAA apply only in federal courts, "intervening developments in the law"-presumably, Supreme Court precedent - required the Court to hold that the FAA applies equally in state courts. ${ }^{125}$ However, Justice Stevens was alarmed by the Southland majority's second holding and its casual dismissal of the saving clause:

For me it is not "clear beyond question that if this suit had been brought as a diversity action in a federal district court, the arbitration clause would have been

\footnotetext{
123 Prima Paint Corp., 388 U.S. at 404. An additional issue arises if the challenge is to the arbitration clause itself: whether the parties agreed to submit questions of arbitrability (as distinct from the underlying merits) to an arbitrator or to a court. On this issue, the Supreme Court has held that the default rule is the court. First Options v. Kaplan, 514 U.S. 938, 944 (1995). Some scholars have argued that First Options introduces ambiguity into the application of the separability rule and Prima Paint. See, e.g., Reuben, supra note 59, at 872-78. But it does not. In First Options, the plaintiff Kaplan had concluded several related contracts with First Options. Some were in his own name; others were on behalf of his wholly owned company. Only the latter contract, however, had an arbitration provision. The arbitrability question was whether the former agreements were also subject to arbitration. 514 U.S. at 940-42. First Options was therefore the very rare case in which only the formation of the agreement to arbitrate - and not the formation of the agreement as a whole - was at issue. The FAA unambiguously declares that this issue is for the court. See 9 U.S.C. $\S 4$ (2012) (conditioning a court's duty to specifically enforce an agreement to arbitrate "upon being satisfied that the making of the agreement for arbitration ... is not in issue") (emphasis added); 9 U.S.C. $§ 3$ (conditioning a court's duty to stay court proceedings pending arbitration on the same). This distinction, between the agreement to arbitration versus the agreement as a whole, is the logic of Prima Paint. See Prima Paint Corp., 388 U.S. at 403; see also supra Section I.B.1 (on dubious origins).

${ }^{124}$ In AT\&T Mobility v. Concepcion, Justice Thomas issued a separate concurrence that mirrors the concerns of Justice Stevens's separate opinion in Southland, specifically, that the scope of preemption implicit in the majority's holding is confusing and threatens to swallow the saving clause. See 563 U.S. $333,353,356$ (2011).

125 Southland, 465 U.S. at 17 (Stevens, J., concurring in part and dissenting in part).
} 
enforceable." The general rule prescribed by $\S 2$ of the Federal Arbitration Act is that arbitration clauses in contracts involving interstate transactions are enforceable as a matter of federal law. That general rule, however, is subject to an exception based on "such grounds as exist at law or in equity for the revocation of any contract." I believe that exception leaves room for the implementation of certain substantive state policies that would be undermined by enforcing certain categories of arbitration clauses. ${ }^{126}$

Justice Stevens's warning has proved apt. Even while documenting how agreements to arbitrate are used to undermine anti-wage-theft policies, consumer protections, and restrictions on employment noncompetes, ${ }^{127}$ the Supreme Court has used Southland to preempt a wide range of state policies embodied in state common law, state statutes, and state constitutions. ${ }^{128}$ Indeed, the Court later held that even federal policies cannot trigger the saving clause. ${ }^{129}$ Only Justice Stevens noticed that Southland implicitly, and without reason, held that the FAA preempts the entire class of contract defenses based on public policy. ${ }^{130}$

\section{Is There Any Limit to Arbitration?}

I conclude this Part by identifying a possible limiting principle to the seemingly unlimited power of arbitrators. I first review the standard of review of arbitral awards. I then offer a potential limiting principle, based on a reinterpretation of "manifest disregard," a judge-made gloss of the FAA's standard of review.

126 Id. at 17-18.

127 See, e.g., DIRECTV, Inc. v. Imburgia, 136 S. Ct. 463 (2015) (consumer contracting); id. at 471 (Ginsburg, J., dissenting); Nitro-Lift Techs., L.L.C. v. Howard, 568 U.S. 17 (2012) (covenants not to compete in employment agreements); Buckeye Check Cashing, Inc. v. Cardegna, 546 U.S. 440 (2006) (consumer credit) and id. at 449 (Thomas, J., dissenting); Perry v. Thomas, 482 U.S. 483 (1987) (wage theft) and $i d$. at 493 (Stevens, J., dissenting).

128 See, e.g., Kindred Nursing Ctrs. Ltd. P'ship v. Clark, 137 S. Ct. 1421, 1426-27 (2017) (state constitution); AT\&T Mobility v. Concepcion, 563 U.S. 333, 339-41 (2011) (state common law); Doctor's Assocs., Inc. v. Casarotto, 517 U.S. 681, 687 (1996) (state statute).

129 See Am. Exp. Co. v. Italian Colors Rest., 570 U.S. 228 (2013). Early Supreme Court decisions had suggested that the saving clause might apply if enforcing an arbitration provision would prevent a party from "effectively . . . vindicat[ing]" a federal cause of action. Id. at 235 (citing Mitsubishi Motors v. Soler Chrysler-Plymouth, Inc., 473 U.S. 614, 637 (1985); 14 Penn Plaza LLC v. Pyett, 556 U.S. 247, 273-74 (2009); and Gilmer v. Interstate/Johnson Lane Corp., 500 U.S. 20, 28 (1991)). But the Court shut this down in 2013. It reasoned that "effective vindication" of a federal claim does not require that a person retain the ability to pursue the federal claim; it merely requires that a person retain the right to bring the claim. Thus, a court may enforce an arbitration provision even if enforcement disables a party from actually bringing the federal claim. See Am. Express, 133 S. Ct. at 235-38 (holding that the "effective vindication" exception does not invalidate a class waiver, even if plaintiff's cost of individually arbitrating the federal claim exceeds the potential recovery); see also id. at 239 (Kagan, J., dissenting).

130 Southland, 465 U.S. at 18 (Stevens, J., concurring in part and dissenting in part). 


\section{The Grounds for Appeal}

Two key features of arbitration enable parties to escape mandatory contract law: (1) arbitrator power and (2) award finality. On the first, the remedial powers of an arbitrator are at least as broad as those of a judge, and possibly more so. ${ }^{131}$ On the second, the FAA limits the grounds under which courts may refuse to enforce an award. These grounds are limited to extreme procedural defects such as "fraud, ... evident partiality or corruption in the arbitrators,... [arbitrator] misconduct[,] ... [and cases in which] the arbitrators exceeded their powers." ${ }^{132}$

The standard of review cannot be altered in contract and leaves no room to consider the merits of an award. ${ }^{133}$ Thus, an arbitrator's award is nearly unappealable. Egregious errors in law or fact are not sufficient grounds for review. ${ }^{134}$ "Of course, decisions procured by the parties through fraud or through the arbitrator's dishonesty need not be enforced," yet "as long as the arbitrator is even arguably construing or applying the contract and acting within the scope of his authority, that a court is convinced he committed serious error does not suffice to overturn his decision." 135

\section{A Possible Limit: Reinterpreting "Manifest Disregard"}

Would any award, regardless of its substance, be enforced so long as it did not evidence procedural defect? A strict interpretation of both the FAA

131 The overwhelming majority of arbitration agreements provide for arbitration per the rules of the American Arbitration Association. These rules give power to the arbitrator to "grant any remedy or relief that the arbitrator deems just and equitable and within the scope of the agreement of the parties." See Commercial Arbitration Rules of the American Arbitration Association, R-47(a) (2013). This includes power to award damages, fees, specific performance and other injunctive relief, as well as power to grant interim or interlocutory awards. See R-47 (scope of award); R-37 (interim measures); R-38 (emergency measures).

1329 U.S.C. $\$ 10$ (2012). The FAA also provides that a court may modify an award in scrivener's error-type cases such as "evident material miscalculation of figures," or to excise a portion of an award "[w] here the arbitrators have awarded upon a matter not submitted to them." Id. § 11.

133 In Hall Street $v$. Mattel, the Supreme Court held that FAA's grounds for review "may [not] be supplemented by contract." 552 U.S. 576, 578 (2008) (referring to Section 9). But see Maureen A. Weston, The Other Avenues of Hall Street and Prospects for Judicial Review of Arbitral Awards, 14 LEWIS \& ClARK L. REv. 929, 949-51 (2010) (analyzing the possibility for parties to draft creative contracts that expand court review of arbitration awards); Christopher R. Drahozal, Contracting Around Hall Street, 14 LEWIS \& CLARK L. REV. 905, 911-16 (2010) (same). The majority's reasoning was mostly premised on the text of the FAA, which, it correctly notes, "carries no hint of flexibility." Hall Street, 552 U.S. at 587. Predictably, however, Hall Street also relied on the usual "national policy favoring arbitration" rationale. The statutory standard of review, it concluded, "substantiat[es] a national policy favoring arbitration with just the limited review needed to maintain arbitration's essential virtue of resolving disputes straightaway." $I d$. at 588 .

134 Hall Street, 552 U.S. at 585-86.

135 United Paperworkers Int'1 Union, AFL-CIO v. Misco, Inc., 484 U.S. 29, 38 (1987). 
and Supreme Court precedent compels the conclusion that, no matter how egregious the error in law, a court must confirm the award.

Yet there must be some limit. At the very least, there are limits outside of arbitration law that would deter a party from asking a court to enforce an agreement to arbitrate. These include, for example, laws that attach criminal liability to price-fixing or human-trafficking agreements. ${ }^{136}$ Further, even if an arbitrator awarded damages for breach of a price-fixing or humantrafficking scheme, it seems unlikely that any court would confirm it. This much seems obvious.

But why is this obvious? Is it because there exists some limiting principle within the FAA or the Supreme Court's arbitration precedent? Strictly speaking, I think not.

There is, however, one doctrine - the "manifest disregard" standardthat, though courts do not expressly declare it as such, I would reinterpret as a limiting principle that responds to this concern. Manifest disregard is a judge-made standard to review arbitration awards. The phrase comes from the Supreme Court's decision in Wilko v. Swan. ${ }^{137}$

The Second Circuit interpreted Wilko as introducing a standard for vacatur outside the FAA. The Second Circuit admitted that the bounds of the new manifest disregard standard were not well-defined, ${ }^{138}$ yet "it clearly means more than error or misunderstanding with respect to the law"139- that is, more than what the FAA allows. The Second Circuit eventually fashioned a two-prong test consisting of objective and subjective components, both of which must be met before a court may refuse to confirm the award. ${ }^{140}$ The objective prong asks "whether the governing law alleged to have been

136 See, e.g., Section 1 of the Sherman Act. 15 U.S.C. $\S 1$. In rare cases, some lower courts have refused to enforce an award on public policy grounds. See, e.g., Connecticut v. AFSCME, Council 4, Local 387, AFL-CIO, 747 A.2d 480 (Conn. 2000); see also Richard C. Reuben, Personal Autonomy and Vacatur After Hall Street, 113 PENN ST. L. REV. 1103, 1113-14 (2009) (discussing such cases). Given the Supreme Court's rejection of unconscionability in Concepcion and its categorical statement on the exclusivity of the grounds for review in Hall Street, it seems likely that, were it to review such cases, the Supreme Court would reverse any lower court refusing to enforce an award on nonstatutory grounds.

137346 U.S. 427 (1953), overruled on other grounds by Rodriguez de Quijas v. Shearson/Am. Exp., Inc., 490 U.S. 477 (1989). As the Supreme Court later summarized:

The Wilko Court was explaining that arbitration would undercut the Securities Act's buyer protections when it remarked (citing FAA $\S 10$ ) that "[p]ower to vacate an [arbitration] award is limited," and went on to say that "the interpretations of the law by the arbitrators in contrast to manifest disregard [of the law] are not subject, in the federal courts, to judicial review for error in interpretation."

Hall Street, 552 U.S. at 584 (citing Wilko, 346 U.S. at 436-37) (internal citations omitted).

138 Merrill Lynch, Pierce, Fenner \& Smith, Inc. v. Bobker, 808 F.2d 930, 933 (2d Cir. 1986).

139 Id.

140 Westerbeke Corp. v. Daihatsu Motor Co., 304 F.3d 200, 209 (2d Cir. 2002). 
ignored by the arbitrators was well defined, explicit, and clearly applicable." 141 The subjective prong "look[s] to the knowledge actually possessed by the arbitrator" and asks whether "the arbitrator appreciated the existence of a clearly governing legal principle but decided to ignore or pay no attention to it." 142

The Supreme Court, however, resisted interpreting manifest disregard as something more than what the FAA allows. In Hall Street v. Mattel, ${ }^{143}$ one of the litigants asked the Supreme Court to recognize manifest disregard as separate grounds for vacating awards. ${ }^{144}$ The Court declined, equating this with a request for "general review for an arbitrator's legal errors." 145 Yet the Court equivocated. It wondered aloud whether Wilko's phrase introduced new grounds for review or was merely a shorthand reference to the statutory grounds collectively. ${ }^{146}$

Given its categorical holding that "the statutory grounds [for vacatur] are exclusive," 147 some courts concluded that manifest disregard did not survive Hall Street. ${ }^{148}$ Others, however, arrived at the opposite conclusion, and the issue arose again in the 2010 case of Stolt-Nielsen v. AnimalFeeds. ${ }^{149}$ The Second Circuit had reasoned that while manifest disregard was not a separate, non-statutory grounds for review, it nevertheless survived Hall Street as a "judicial gloss" on the statutory grounds of Section 10. ${ }^{150}$ The Second Circuit then applied the manifest disregard "gloss" to vacate an arbitration award. ${ }^{151}$

\footnotetext{
141 Id. (citing Merrill Lynch, 808 F.2d at 934) (internal quotations and alterations omitted).

${ }^{142} I d$.

143552 U.S. 576 (2008).

${ }^{144} \mathrm{Id}$. at 584 .

$145 I d$. at 585.

${ }^{146}$ Id.; see also Robert Ellis, Imperfect Minimalism: Unanswered Questions in Hall Street Associates, L.L.C. v. Mattel, Inc., 128 S. Ct. 1396 (2008), 32 HARV. J.L. \& PUB. POL'Y 1187, 1191-93 (2009) (explaining how the Supreme Court's dicta created uncertainty among the lower courts).

147552 U.S. at 578.

148 See, for example, the discussion in Stolt-Nielsen SA v. AnimalFeeds Int'l Corp., 548 F.3d 85, 94 (2d Cir. 2008).

149559 U.S. 662, 670 (2010).

150 Stolt-Nielsen, 548 F.3d at 94, rev'd and remanded sub nom. Stolt-Nielsen S.A. v. AnimalFeeds Int'l Corp., 559 U.S. 662 (2010).

151 The Second Circuit explained:

Like the Seventh Circuit, we view the "manifest disregard" doctrine, and the FAA itself, as a mechanism to enforce the parties' agreements to arbitrate rather than as judicial review of the arbitrators' decision. We must therefore continue to bear the responsibility to vacate arbitration awards in the rare instances in which the arbitrator knew of the relevant legal principle, appreciated that this principle controlled the outcome of the disputed issue, and nonetheless willfully flouted the governing law by refusing to apply it.
} 
The Supreme Court granted certiorari but again avoided the manifest disregard question by affirming the Second Circuit decision on statutory grounds. It held that the arbitrator had exceeded its powers by expressly basing the award on its own public policy judgment (instead of on applicable law). ${ }^{152}$ Further, it expressly declined to decide whether manifest disregard survived Hall Street, ${ }^{153}$ though it did awkwardly leave the door open by asserting that, if the standard did apply, it would have been satisfied in this case. ${ }^{154}$

I think the Stolt-Nielsen Court unintentionally but effectively incorporates a limiting principle into the statutory grounds for vacatur. It accomplished this by holding, as a matter of law, that an arbitration panel which imposes its own policy choice "exceeds its powers" under Section $10 . .^{155}$ In this way, Stolt-Nielsen smuggles the subjective prong of manifest disregard - that "the arbitrator must appreciate the existence of a clearly governing legal principle but decide[] to ignore or pay no attention to it"156 - into one of the FAA's statutory grounds for vacatur, namely, excession of powers. ${ }^{157}$

Stolt-Nielsen, 548 F.3d at 95 (alterations omitted). The Second Circuit's argument is flawed. Stripped to its essentials, it offers prudential grounds for the proposition that something akin to "willful misapplication of the law" should be grounds for vacating an award. This argument ignores Hall Street's holding that the statutory grounds are exclusive. However, the Second Circuit's conclusion - that manifest disregard survives Hall Street - could be supported. A more logically sound argument would support that conclusion by reasoning either (1) the statutory grounds in Section 10 collectively imply manifest disregard, or (2) manifest disregard is a specific instance of one of Section 10's grounds. Indeed, on (2), one could argue that "willful misapplication of the law" is an instance of one of the statutory grounds in Section 10(4), namely, the case in which "the arbitrators ... so imperfectly executed [their powers] that a mutual, final, and definite award upon the subject matter submitted was not made." 9 U.S.C. $\$ 10(\mathrm{a})(4)(2012)$.

152 Stolt-Nielsen, 559 U.S. at 676-77.

153 Id. at 672 n.3.

154 Id.

$155 I d$. at 677.

156 Westerbeke Corp. v. Daihatsu Motor Co., 304 F.3d 200, 209 (2d Cir. 2002) (citing Merrill Lynch, Pierce, Fenner \& Smith, Inc. v. Bobker, 808 F.2d 930, 933 (2d Cir. 1986)) (internal quotations and alterations omitted).

157 Excession of powers was traditionally equated with "exceeding the submission," that is, the case in which an arbitrator decided on issues that were not properly submitted for arbitration, either because the parties themselves did not request an award on the issue, or because it is outside of the scope of the parties' agreement to arbitrate. See, e.g., De Groot v. United States, 72 U.S. (5 Wall) 419, 430-31 (1866). After the FAA, the Supreme Court held close to the understanding that excession of powers is limited to cases in which the arbitrator strays from the agreement.

[A]n arbitrator is confined to interpretation and application of the [agreement]; he does not sit to dispense his own brand of industrial justice. He may of course look for guidance from many sources, yet his award is legitimate only so long as it draws its essence from the [agreement]. When the arbitrator's words manifest an infidelity to this obligation, courts have no choice but to refuse enforcement of the award. 
This limiting principle, however, has its own limits. It is based not on an arbitrator's actual knowledge that the award is not based on applicable law, but rather on the arbitrator's normative vision of applicable law. ${ }^{158}$ Thus, this principle would not apply to an arbitrator who interprets a choice of law provision as valid (even if a court would not) and then applies that law to enforce the contract. Moreover, the principle would require some record of the arbitrator's reasoning - yet arbitrators are under no obligation to create one, or indeed provide any reason to support their award. ${ }^{159}$

A more robust limiting principle would be based not on subjective but on constructive knowledge, though, to be fair, such a standard might risk relitigation of every award. In any event, it remains to be seen precisely how this limiting principle applies to cases in which there is no evidence of the arbitrator's subjective beliefs or reasoning.

\section{E. Conclusion}

In summary, this Part chronicled the rise of federal arbitration preemption and the concomitant decline in states' authority to craft and enforce contract law. These developments, however, have practical effect only to the extent that contract parties agree to arbitrate their disputes. To the best of my knowledge, no previous study has presented nationally representative figures documenting the extent to which parties agree to arbitrate. The next Part thus endeavors to provide such figures for the first time.

\section{NEW EVIDENCE ON THE PERVASIVENESS OF EMPLOYMENT ARBITRATION}

This Part presents new evidence on the pervasiveness of employment arbitration. Section A describes the data collection process, and Section B presents the results.

United Steelworkers of Am. v. Enter. Wheel \& Car Corp., 363 U.S. 593, 597 (1960). But in Stolt-Nielsen, the Court seized upon the language of an arbitrator "dispens[ing] his own brand of industrial justice" in its holding that straying from the agreement includes, in effect, straying from the application of the law. Stolt-Nielsen, 559 U.S. at 671-72.

158 Stolt-Nielsen, 559 U.S. at 672 ("[T] he task of an arbitrator is to interpret and enforce a contract, not to make public policy."). There are a handful of other, though much rarer, nonstatutory grounds upon which some lower courts have refused to enforce an award. See Reuben, supra note 136, at 1113-16 (summarizing these grounds).

${ }^{159}$ Both U.S. courts and the American Arbitration Association leave it to the discretion of the parties and the arbitrator. See, e.g., United Steelworkers of Am., 363 U.S. at 598 ("Arbitrators have no obligation to the court to give their reasons for an award."); see also Commercial Arbitration Rules of the American Arbitration Association, R-46(b) (2013) ("The arbitrator need not render a reasoned award unless the parties request such an award in writing prior to appointment of the arbitrator or unless the arbitrator determines that a reasoned award is appropriate."). 


\section{A. Data Collection}

I used standard natural language processing tools to create a dataset of roughly 800,000 contracts from all U.S. public companies between 1996 and 2016. The contracts come from filings submitted to the Securities and Exchange Commission (SEC). In general, a company must file reports to the SEC if it has made a public offering or has "total assets exceeding $\$ 10,000,000$ and a class of equity security ... held [by at least] 2,000 persons." 160 Companies that report to the SEC must disclose any "contract not made in the ordinary course of business which is material to the [company]." 161 This includes, among others, contracts to which directors and officers are parties. ${ }^{162}$ Companies report material contracts by attaching them as exhibits to filings submitted to the SEC, such as on the periodic and interim reports submitted through forms 10-K, 10-Q, and 8-K. ${ }^{163}$ The SEC makes all filings since 1996 available online on the EDGAR database. ${ }^{164}$

To recover the contracts, I wrote a program to search through all SEC filings. SEC filings use a unique code to identify material contracts. ${ }^{165}$ Thus, this process recovered every contract disclosed to the SEC since 1996. I then parsed each contract for several variables: contract type, arbitration provision, and choice of law. The sample only includes contracts that are governed by the law of a U.S. state. Also, in the table below, I report the results for arbitration rates separately for the fifteen most common contract categories. These include fourteen distinct categories and a fifteenth category for "other."

160 Securities Exchange Act $§ 12(\mathrm{~g})$; 15 U.S.C. $§ 78(1)$ (2012).

16117 C.F.R. $\$ 229.601(b)(10)$ (2018). Any "material contract or plan of acquisition, reorganization, arrangement, liquidation or succession . . . [must] be filed as an exhibit to the Form 10-Q or Form 10-K." 17 § C.F.R. 229.601(a)(4). In response to the Sarbanes-Oxley Act § 409, 15 U.S.C. § 78(m) (2012), which calls for "real time issuer disclosures," the SEC has required firms to disclose a summary of any "material definitive agreement not made in the ordinary course of business." See Securities and Exchange Commission, Final Rule: Additional Form 8-K Disclosure Requirements and Acceleration of Filing Date [Release Nos. 33-8400; 34-49424; File No. S7-22-02], SEC. \& ExCH. COMM'N (Mar. 25, 2004), https://www.sec.gov/rules/final/33-8400.htm [https://perma.cc/V7NU-3DWJ].

162 Reporting companies must disclose contracts "to which directors, officers, promoters, voting trustees... or underwriters are parties," "upon which the registrant's business is substantially dependent," "[involving] the acquisition or sale of any property... exceeding 15 percent of [the company's] fixed assets," and "[a]ny management contract or . . compensatory plan." 17 § C.F.R. 229.601(b)(10)(ii)(A)-(D)(iii)(A).

163 Reporting companies must file these forms pursuant to Sections 13 or 15(d) of the Securities Exchange Act of 1934.

164 Filing \& Forms, SEC. \& EXCH. COMM'N (last modified Jan. 9, 2017), http://www.sec.gov/edgar.shtml [https://perma.cc/FBA3-29JB]. For a handful of companies, the earliest forms available online are from 1993.

165 Specifically, registrants follow a numbering convention to distinguish material contracts from other types of exhibits. The code for material contracts is "Exhibit 10." 
A human-coded audit was conducted to check the accuracy of the machine coding. The audit checked the accuracy of the algorithm for choice of law and arbitration for 1000 randomly selected contracts. The algorithm successfully coded the choice of law clause for $98.1 \%$ of contracts. It also successfully coded the arbitration clause for $99.3 \%$ of contracts.

\section{B. Results}

Table 2 shows how arbitration rates vary by contract type. There are 791,362 total contracts in the sample. The average arbitration rate across all contracts is $19 \%$.

Employment agreements have the highest rate of arbitration, at $42 \%$. The type of contract least likely to include an arbitration provision is credit agreements, at $4 \%$. Employment agreements and credit agreements are also the two most common types of contracts in the sample. Each account for about $20 \%$ of all contracts disclosed to the SEC.

TABle 2: ARbitration RATE by CONTRACt TyPE

\begin{tabular}{|l|c|c|c|}
\hline & Arbitration Rate & Share of Total & $\begin{array}{c}\text { Number of } \\
\text { Contracts }\end{array}$ \\
\hline Employment & 0.42 & 0.18 & 140,980 \\
\hline Joint Venture & 0.31 & 0.01 & 4,869 \\
\hline Service & 0.30 & 0.05 & 39,592 \\
\hline Settlement & 0.27 & 0.09 & 74,953 \\
\hline Consulting & 0.24 & 0.02 & 13,957 \\
\hline Lease & 0.21 & 0.03 & 27,467 \\
\hline Merger & 0.21 & 0.01 & 9,561 \\
\hline Purchase & 0.18 & 0.10 & 79,459 \\
\hline Other & 0.17 & 0.09 & 67,880 \\
\hline Insurance & 0.17 & 0.05 & 36,328 \\
\hline $\begin{array}{l}\text { Shareholders } \\
\text { Agreement }\end{array}$ & 0.16 & 0.01 & 7,878 \\
\hline Pension & 0.14 & 0.02 & 13,731 \\
\hline Partnership & 0.14 & 0.01 & 10,623 \\
\hline $\begin{array}{l}\text { Negotiable } \\
\text { Instrument }\end{array}$ & 0.05 & 0.12 & 96,561 \\
\hline Credit & 0.04 & 0.21 & 167,523 \\
\hline Total & $\mathbf{0 . 1 9}$ & $\mathbf{1 . 0 0}$ & $\mathbf{7 9 1 , 3 6 2}$ \\
\hline
\end{tabular}

Figure 2 presents the trend in arbitration rates over time. Specifically, it graphs the arbitration rate each year, separately for employment agreements and all others. "All others" thus includes the fourteen categories besides employment. The arbitration rate for employment and non-employment contracts has been roughly constant for the last twenty years. 
I draw two conclusions from these data. First, employment arbitration is common, both in an absolute and relative sense. Second, given the stability of employment arbitration rates over time, it seems likely that employment arbitration will remain common in the future.

\section{The Principal Challenge of Machine Learning in Empirical Legal Studies}

Finally, it is worth reflecting on a limitation of this empirical section. The empirical section was initially motivated by the case of Nitro-Lift $v$. Howard (discussed in the Introduction), in which an employer used arbitration to enforce an otherwise invalid noncompete provision. In previous work, I had found that noncompetes were common even in jurisdictions that expressly void them. ${ }^{166}$ The initial goal of the empirical section was thus to investigate the relationship between arbitration and noncompete provisions using machine learning protocols.

This goal, however, was not realized. A hand-coding audit revealed that the typical words and phrases used to craft noncompete provisions substantially overlapped with those of other common secrecy provisions, such as nonsolicitation and confidentiality provisions. For this reason, the standard machine learning protocols that successfully identified employment agreements and arbitration provisions were relatively unsuccessful at distinguishing noncompetes from other secrecy provisions.

This example speaks to a more general challenge-perhaps the principal challenge - facing scholars who use machine learning protocols to study legal texts. Loosely speaking, one might imagine a spectrum of questions to ask of a legal text, ranging from the very specific to the very general. On one extreme lie questions involving specific facts, such as: "Did the parties choose litigation or arbitration?" or "Who is the plaintiff?" On the other extreme lie questions involving very general concepts, such as: "Is this an employment contract?" or "Is this a judicial opinion?"

In my view, the literature has tended toward questions at these extremes because they are relatively well-suited to machine learning protocols-but the real action lies in the middle ground. In the middle ground are questions such as: "Have the parties agreed not to compete with each other?" or "Does the judicial opinion approve the use of legislative history?" These questions, while susceptible to reliable human coding, are tricky for the machine because they demand precise applications of broad concepts - such as "competition" or "statutory interpretation"- that evade algorithmic

\footnotetext{
${ }^{166}$ See Sarath Sanga, Incomplete Contracts: An Empirical Approach, 34 J.L. ECON. \& ORG. 650
} (2018). 
definition. Answering these questions with machine learning protocols would effectively enable scholars to apply (rudimentary) legal reasoning at scale. Thus, the challenge for the emerging literature that applies machine learning techniques is to resist the temptation of low-hanging questions lying at the extremes, and instead develop methods for addressing the more stubborn, yet perhaps more fruitful, questions that live in the middle.

Figure 2: Share of CONTRACTS With ARbitration Provisions

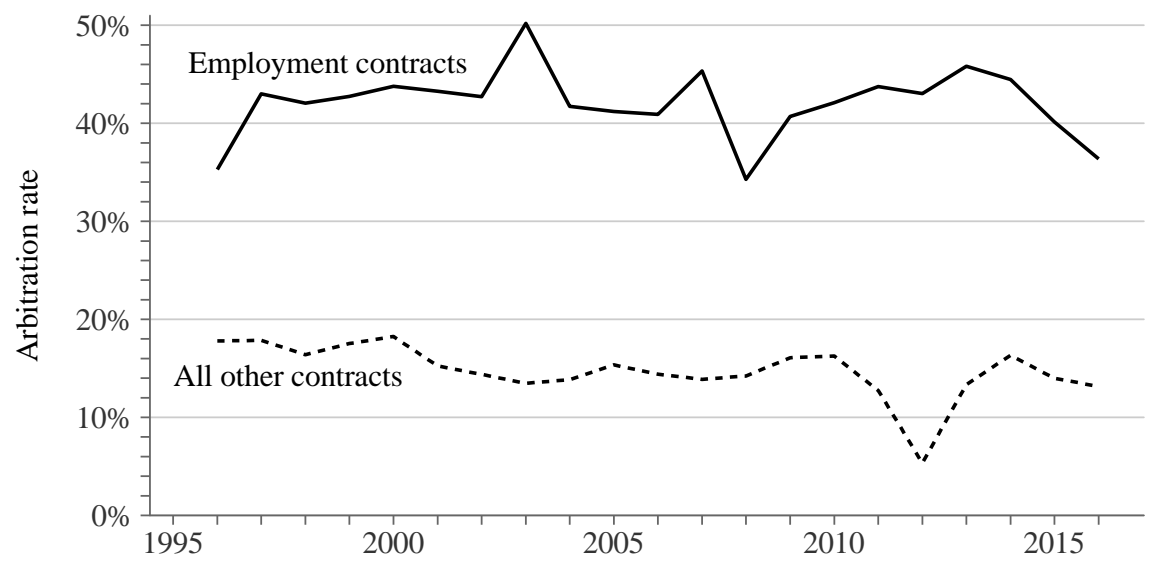

\section{WHAT STATES CAN DO}

In this Part, I outline a new strategy for states in response to the problems outlined in Part I. Federal arbitration law effectively eliminates states' ability to enforce, or monitor enforcement of, their own laws in contract actions. Section A describes the proposed solution: Focus on deterring the formation of contracts that, if performed, would contravene state policy. Section B uses two examples to explore the details of implementing this strategy.

\section{A. The Strategy: Deterrence over Enforcement}

States cannot directly regulate arbitration, and the only way to change this is through congressional action. Congress has previously limited the scope of the FAA in several contexts, such as in motor vehicle franchise agreements, consumer credit agreements, whistleblower-related actions, and sales of securities (though some federal laws limiting the scope of the FAA were later repealed). ${ }^{167}$ But recent efforts to enact limits to the FAA's reach

167 See, e.g., Commodity Exchange Act, 7 U.S.C. § 26(n)(2) (2012) (invaliding agreements to arbitrate that would otherwise interfere with the Act's whistleblower incentives); Military Lending Act, 
in the workplace, particularly to prohibit forced arbitration of sexual harassment, have been unsuccessful. Given the current congressional climate, it seems unlikely that these initiatives will be successful in the near future. ${ }^{168}$

States, however, can act without Congress. To do so, they must change the way they enforce policies. Rather than relying on contract enforcement (or nonenforcement), states should deter formation of contracts that contravene public policy. I next consider two examples. The first example shows how states can indirectly enforce state policies on noncompetes by deterring parties from forming noncompete agreements (rather than directly enforcing the policy in contract actions). The second example shows how states can prevent mandatory arbitration of civil rights claims by deterring formation of certain types of arbitration agreements.

\section{B. Example 1: Indirect Enforcement}

\section{The Case of Covenants Not to Compete}

States place a variety of limits on the enforceability of noncompetes. Some states, such as California and Oklahoma, void noncompetes outright. ${ }^{169}$ Nearly all other states enforce covenants not to compete in employment contracts as long as the restriction is "reasonable." The reasonableness test

10 U.S.C. $§ 987(e)(3)$ (2012) (prohibiting mandatory arbitration provisions in consumer credit contracts with service members and their dependents); Dodd-Frank Wall Street Reform and Consumer Protection Act, 15 U.S.C. $§ 780$ (o) (2012) (granting the Securities and Exchange Commission authority to regulate arbitration agreements between securities dealers and their customers and prohibiting lenders from including mandatory arbitration provisions in mortgage contracts) (implemented by 12 C.F.R. $\S 1026.36(\mathrm{~h})$ but later repealed by Pub. L. No: 115-74 of November 1, 2017); see also Exec. Order No. 13,673 of July 31, 2014, 79 Fed. Reg. 45,309 (Aug. 5, 2014) (prohibiting mandatory arbitration of certain federal procurement contracts) (revoked by Exec. Order No. 13,782 of Mar. 27, 2017, 82 Fed. Reg. 15,607 (Mar. 30, 2017)); Motor Vehicle Franchise Arbitration Fairness Act, 15 U.S.C. § 1226(a)(2) (2012) (providing that predispute arbitration provisions in motor vehicle franchise contracts are unenforceable).

168 See Arbitration Fairness Act of 2011, S. 987, 112th Cong. (2011); see also Restoring Statutory Rights and Interests of the States Act of 2017, S. 550; 115th Cong. § 2(a)(4) (2017). Section 2(a)(4) of the latter provides a statement of congressional intent: "States have a compelling interest in enacting rights and remedies to protect the welfare of their citizens, and the Federal Arbitration Act should not be, and should not have been, interpreted to preempt State legislation that enacted rights and remedies to protect the welfare of their citizens."

169 See CAL. BUS. \& PROF. CODE $\S 16600$ (West 2018) (providing that "every contract by which anyone is restrained from engaging in a lawful profession, trade, or business of any kind is to that extent void"). California courts have emphasized that there are no exceptions to this rule. See Whyte v. Schlage Lock Co., 101 Cal. App. 4th 1443, 1462-63 (Cal. Ct. App. 2002); see also Edwards v. Arthur Andersen LLP, 189 P.3d 285, 293 (Cal. 2008) (rejecting the Ninth Circuit's "narrow restraint" exception). Montana, North Dakota, and Oklahoma also have similar blanket prohibitions. See MonT. CodE ANN. § 28-2-703 (2017); N.D. CENT. CodE § 9-08-06 (2018); OKLA. StAT. ANN. tit. 15, § 217 (West 2018). 
is typically formulated as a limitation on the time and geographic scope of the noncompete. ${ }^{170}$

The economic rationale for limiting freedom of contract in this way can be divided into two categories: to protect parties inside the contract and to protect parties outside the contract. ${ }^{171}$ On the first, limiting enforcement of noncompetes protects vulnerable employees with little or no bargaining power. These employees are unlikely to have access to counsel, and therefore may not appreciate precisely how noncompetes limit their future employment. Indeed, a large body of empirical literature documents that laypersons do not read agreements or understand their contractual liabilities. ${ }^{172}$ Thus, many employees may not even be aware that they are subject to a noncompete. Limiting enforcement of noncompetes also protects parties outside the contract. Noncompetes negatively affect society, as other employers are unable to hire persons subject to noncompetes. Thus, a policy of not enforcing noncompetes promotes labor market mobility and information spillovers, both of which generate innovation. ${ }^{173}$ However, noncompetes may also produce welfare benefits. For example, they may incentivize employers to invest in their employees' human capital. ${ }^{174}$ An optimal policy, therefore, must balance these competing interests.

The problem with states' noncompete policies, however, is that they are unenforceable in practice. Private parties can contract around them with arbitration and choice of law. This was the issue in Nitro-Lift v. Howard, as discussed in the Introduction. ${ }^{175}$ That case involved an employee from Oklahoma, where noncompetes are categorically banned. The simple runaround required the employee to arbitrate under the laws of a jurisdiction that permits noncompetes - in that case, Louisiana. If the contract did not include an arbitration provision and were instead litigated, an Oklahoma state court would invalidate the choice of law provision, apply Oklahoma law, and thus

\footnotetext{
170 See, e.g., Reed, Roberts Assocs., Inc. v. Strauman, 40 N.Y.2d 303, 307 (1976) (“[A] restrictive covenant will only be subject to specific enforcement to the extent that it is reasonable in time and area, necessary to protect the employer's legitimate interests, not harmful to the general public and not unreasonably burdensome to the employee.").

171 See, e.g., Ian Ayres \& Robert Gertner, Filling Gaps in Incomplete Contracts: An Economic Theory of Default Rules, 99 YALE L.J. 87, 88 (1989).

172 See, e.g., Yannis Bakos et al., Does Anyone Read the Fine Print? Consumer Attention to Standard-Form Contracts, 43 J. Legal STUD. 1, 3 (2014); Ian Ayres \& Alan Schwartz, The No-Reading Problem in Consumer Contract Law, 66 STAN. L. REv. 545, 546 (2014).

173 See, e.g., Ronald J. Gilson, The Legal Infrastructure of High Technology Industrial Districts: Silicon Valley, Route 128, and Covenants Not to Compete, 74 N.Y.U. L. REv. 575 (1999) (arguing that California's noncompete policy would have such effects).

174 See, e.g., Mark J. Garmaise, Ties that Truly Bind: Noncompetition Agreements, Executive Compensation, and Firm Investment, 27 J. L. ECON. \& ORG. 376 (2011).

175568 U.S. 17 (2012).
} 
void the noncompete. One might think that Oklahoma law would still be enforced so long as the arbitrator applies the correct conflict of laws analysis. The problem is that an arbitrator may not be so inclined. Indeed, the Supreme Court has all but encouraged arbitrators to ignore conflict of laws. ${ }^{176}$

\section{The Policy Strategy}

Given that the Supreme Court has effectively enabled parties to opt out of state policy, what should states do? Since states can do nothing about enforcement, the answer is that they should instead deter formation of noncompete agreements. For example, a state could issue civil fines against employers that form noncompetes with employees and enforce this by offering employees whistleblower rewards to report violations. The essential legal feature of this approach is that it creates a structure in which vindicating the policy (that is, eliminating noncompetes) does not require an action in contract. The creation of such a mechanism is necessary, since these actions will be sent to arbitration and cannot be monitored.

More generally, states should develop clear rules concerning noncompetes, and then prohibit formation of contracts that do not adhere to these rules. In this way, states may calibrate their noncompete policy without relying on arbitration for enforcement. Instead of using the ubiquitous "reasonableness" test of most jurisdictions, states should enact simple rules as to time and geography. For example, the maximum scope for, say, New York, might be "two years, within the state of New York, and within an industry defined by the Global Industrial Standard Classification." Then, New York could adopt the same mechanism - a whistleblower incentive for employees - to deter formation of agreements that exceed these clear limits.

No state has expressly adopted such an approach, but some states have come close. In the Illinois Freedom to Work Act, Illinois recently prohibited noncompetes for "low-wage" employees (defined by the employee's hourly

\footnotetext{
176 In its concluding paragraph in Circuit City Stores, Inc. v. Adams, the Court explains why:

We have been clear in rejecting the supposition that the advantages of the arbitration process somehow disappear when transferred to the employment context. Arbitration agreements allow parties to avoid the costs of litigation, a benefit that may be of particular importance in employment litigation, which often involves smaller sums of money than disputes concerning commercial contracts. These litigation costs to parties (and the accompanying burden to the courts) would be compounded by the difficult choice-of-law questions that are often presented in disputes arising from the employment relationship, and the necessity of bifurcation of proceedings in those cases where state law precludes arbitration of certain types of employment claims but not others.
}

532 U.S. 105, 123 (2001) (emphasis added) (internal citations omitted). It added that arbitration generally avoids the "complexity and uncertainty" of such issues. $I d$. 
wages). ${ }^{177}$ The problem with this law is that it was not coupled with an easy mechanism for private enforcement-i.e., whistleblower incentives of the kind explained above. Further, there is no clear schedule of fines associated with violations. There is therefore little to deter employers from flouting the prohibition, especially against uninformed employees.

The first high-profile suit brought by the Illinois Attorney General under the shadow of the new Illinois statute demonstrates its limits. ${ }^{178}$ The suit challenged the sandwich chain Jimmy John's and its practice of including noncompetes in its contracts with rank-and-file employees. ${ }^{179}$ Illinois's position was that these noncompetes were not permitted under existing common law. ${ }^{180}$

Jimmy John's "defense" was that, even if the noncompetes were unenforceable, it never tried to enforce the noncompete. ${ }^{181}$ This is nonsense. The power of a noncompete against a rank-and-file employee is in the threat, not the execution. Thus, an employer could include the provision in a standard form contract, never enforce it, and still discourage at least some employees from competing. Further, even a sophisticated rank-and-file employee who knows her legal obligations may hesitate to "breach" this unenforceable agreement, if only for fear of costly arbitration. In the settlement, Jimmy John's agreed to pay $\$ 100,000$ to raise awareness of the new noncompete law. Without a robust whistleblower regime, however, it is difficult to see how this will deter future violations of the new statute.

\footnotetext{
177 See 820 Ill. COMP. StAT. ANN. 90/10 (West 2018). The Act was passed partially in response to Illinois courts' increased scrutiny of employment noncompetes. See, e.g., Fifield v. Premier Dealership Servs., 993 N.E.2d 938 (Ill. App. Ct. 2013).

178 The new statute did not apply to this case. The Jimmy John's suit settled in December 2016, while the new statute applied only to contracts formed on or after January 1, 2017.

179 See Complaint, People v. Jimmy John's Enters., LLC, No. 2016-CH-07746 (Ill. Cir. Ct. June 8, 2016), available at https://will.illinois.edu/nfs/JimmyJohnsComplaintFILED.pdf [https://perma.cc/ J2DV-Q27E].

180 Illinois Attorney General Lisa Madigan claimed that Jimmy John's "lack[ed] any legitimate business interest to justify the [noncompete] agreements, the agreements [were] not supported by adequate consideration, and the agreements [were] not narrowly tailored." $I d$. at 2.

181 Jimmy John's cited a similar case filed in the United States District Court for the Northern District of Illinois, in which employees of Jimmy John's sought a declaratory judgment to determine the enforceability of the noncompete. The court held that the employees lacked standing to pursue the claim because they did not allege that Jimmy John's had enforced the noncompete against them at any point in the past, and because they did not possess "a reasonable fear of litigation." See Brunner v. Liautaud, No. 14-C-5509, 2015 WL 5086388, at *24-31 (N.D. Ill. Apr. 8, 2015).
} 


\section{Example 2: Preventing (Mandatory) Arbitration}

\section{The Case of Civil Rights Claims}

Arbitration provisions in employment contracts are typically broad in scope, providing for arbitration for "any dispute" that arises during employment. Until recently, it was not clear whether such provisions could lawfully include all civil rights claims.

The question was settled in 1991. In Gilmer v. Interstate/Johnson Lane Corp., the U.S. Supreme Court held that employers and employees can specifically enforce predispute agreements to arbitrate claims arising under the Age Discrimination in Employment Act. ${ }^{182}$ Then, later in the same year, Congress passed the Civil Rights Act of 1991. In it, Congress specifically encourages arbitration of all civil rights claims: "Where appropriate and to the extent authorized by law, the use of alternative means of dispute resolution, including settlement negotiations, conciliation,... and arbitration, is encouraged to resolve disputes arising under the Acts or provisions of Federal law amended by this title." 183 To the best of my knowledge, this is the first express statement by the Congress in support of a "national policy favoring arbitration."

Employers and employees are both enabled and encouraged to keep civil rights claims out of public courts. Yet states and the public have an interest in encouraging the opposite. They have an interest in both monitoring enforcement of civil rights in the workplace and affording employees certain procedural protections. Given these interests, how can states bring civil rights disputes back into public courts?

\section{The Policy Strategy}

The strategy is to craft a law that does not interfere with the arbitral process - and therefore avoids preemption. Any law must allow arbitration of civil rights claims to proceed. For example, a simple law prohibiting mandatory arbitration of sexual harassment claims - such as the one recently passed by New York ${ }^{184}$ — would, if challenged, surely be preempted by the FAA.

Further complicating the issue, even if states could prohibit arbitration of all civil rights claims, it is not obvious whether they should. Some employees may prefer to arbitrate their civil rights claims, and so compelling

\footnotetext{
182500 U.S. 20,28 (1991).

18342 U.S.C. § 1981 (2012); see also Mara Kent, "Forced” vs. Compulsory Arbitration of Civil Rights Claims, 23 LAW \& INEQ. 1, 97-99 (2005) (discussing the Civil Rights Act of 1991).

184 N.Y.C.P.L.R. 7515 (McKinney 2018); see also California measure AB 3080, introduced into the senate on March 31, 2018 (proposed state legislation to prohibit forced arbitration of sexual harassment claims).
} 
public litigation in such cases may only compound the harm. In principle, therefore, state policy should be designed to empower employees to choose their forum after the dispute has arisen, or, equivalently, to incentivize employers to grant employees this option.

States can achieve this by first prohibiting civil rights as a subject matter for contracts. After enacting this prohibition, the law could then carve out an exemption for post-dispute agreements so that parties may still settle existing claims. An example of such a law is as follows:

(1) No person shall enter into an agreement with any employee concerning the civil rights of the employee. All such agreements are illegal and void.

(2) Section 1 shall not apply to agreements concerning existing legal claims.

Private enforcement could then proceed as in the noncompete example. For example, employees could be empowered to bring a qui tam action on behalf of the state to enforce the law. Even if a state does not intervene, these actions cannot be sent to arbitration. ${ }^{185}$ To implement this, states can simply copy existing state and federal statutes that enable qui tam actions. ${ }^{186}$

This law is not preempted by the FAA for several reasons. First, the law does not "derive [its] meaning from the fact that an agreement to arbitrate is at issue." 187 Rather, it derives its meaning from the fact that the subject matter of the agreement relates to the employee's civil rights. Indeed, employers can violate this law with or without requiring employees to arbitrate civil rights disputes; further, employers may still require employees to arbitrate civil rights disputes even under this law.

To see this, consider the following examples. Suppose an employment contract prohibits the employee from disclosing any instance of sexual harassment. This contract violates the law regardless of whether it includes an arbitration agreement, and so the employer would be subject to civil penalties. Next suppose an employment contract includes an agreement to arbitrate and the employee files suit against the employer alleging sexual harassment. Under the FAA, a court would be compelled to submit the claim

185 In Iskanian v. CLS Transp. L.A., LLC, 59 Cal. 4th 348, 386-87 (2014), the Supreme Court of California held that employees cannot waive their right to bring representative claims under California's Private Attorneys General Act - that is, claims seeking civil penalties against employers for labor code violations against other employees - because those claims belong to, and are brought on behalf of, the state, which is not a party to the employment contract; see also Sakkab v. Luxottica Retail N. Am., Inc., 803 F.3d 425, 426 (9th Cir. 2015) (holding that the Iskanian rule is not preempted by the FAA).

186 See, e.g., California's Labor Code Private Attorneys General Act of 2004, CAL. LAB. CODE $\S \S 2698-2699.5$; California’s False Claims Act, CAL. Gov’T. CODE $§ 12650$ (West 2005); Federal False Claims Act, 31 U.S.C. $\$ 3730(b)$ (2012).

187 AT\&T Mobility v. Concepcion, 563 U.S. 333, 339 (2011) (citing Doctor's Assocs., Inc. v. Casarotto, 517 U.S. 681, 687 (1996)); Perry v. Thomas, 482 U.S. 483, 492-93 n.9 (1987). 
to arbitration-leaving the arbitrator to decide whether the arbitration may procced. The proposed law does nothing to alter this result. Instead, it only subjects the employer to fines that the state itself may collect directly from the employer. Again, these fines are not a consequence of the arbitration agreement. They arise because the employer contracted over the employee's civil rights.

The law also does not interfere with the "fundamental attributes" of arbitration or "disfavor[] contracts that (oh so coincidentally) have the defining features of arbitration agreements." 188 The law does not regulate any aspect of the arbitral process or enable a court to refuse to enforce an arbitration agreement under any circumstance.

Though this Article does not advocate it, it is worth considering an even simpler approach: prohibiting employment contracts altogether. There are many legal and economic arguments one might make against such a "brute force" law. Yet there is no argument that such a law would be preempted by the FAA since, as per the Supreme Court's requirement, ${ }^{189}$ it expressly applies to "any" contract. It does not "single out" arbitration. ${ }^{190}$

Finally, it is worth observing that policies like the one suggested herethat is, prohibitions of certain classes of contracts - are commonplace. Two examples that come to mind are prohibitions on agreements to collude among competitors ${ }^{191}$ and prohibitions on bribery contracts between American companies and foreign governments. ${ }^{192}$

\section{CONCLUSION}

This Article showed how the last fifty years of Supreme Court arbitration jurisprudence has effectively enabled employers and employees to opt out of mandatory state law. It also presented new evidence on the pervasiveness of employment arbitration by parsing millions of filings with the SEC to create a database of nearly 800,000 contracts. Among all types of contracts-purchases, joint ventures, credit agreements, and othersemployment agreements are by far the most likely to include an arbitration provision.

188 Kindred Nursing Ctrs. Ltd. P'ship v. Clark, 137 S. Ct. 1421, 1426 (2017); see also Concepcion, 563 U.S. at 344 (holding that "[r]equiring the availability of classwide arbitration interferes with fundamental attributes of arbitration and thus creates a scheme inconsistent with the FAA").

189 Epic Sys. Corp. v. Lewis, 138 S. Ct. 1612, 1622 (2018).

190 Id. at 1646 ("States may enforce generally applicable rules so long as they do not single out arbitration for disfavored treatment." (citing Kindred Nursing Ctrs., 137 S. Ct. at 1428 n.2)).

191 See Sherman Antitrust Act, 15 U.S.C. $\$ 1$ (2012).

192 See Foreign Corrupt Practices Act, 15 U.S.C. $\S ~ 78 d d-1$, (a)-(b) (2012). 
In response to these trends, I offered a new strategy to states to regulate arbitration. Federal law would preempt any direct state effort to regulate arbitration or prohibit employment disputes from being arbitrated. I therefore proposed that states abandon contract enforcement as a policy lever, and instead focus on deterring formation of contracts that would undermine state policy. 
NORTHWESTERN UNIVERSITY LA W REVIEW 